\title{
Reduction resistant and rigid nitroxide spin labels for DNA and RNA
}

\author{
Haraldur Yngvi Juliusson and Snorri Th. Sigurdsson* \\ University of Iceland, Department of Chemistry, Science Institute, Dunhaga 3, 107 Reykjavik, \\ Iceland.
}

*E-mail: snorrisi@hi.is

\section{Table of contents}

Spin-labeled oligonucleotides and their analysis by MS and EPR spectroscopy . ...................

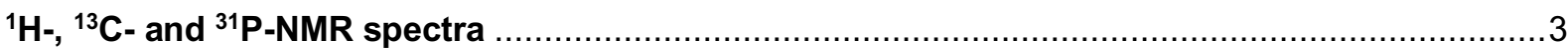

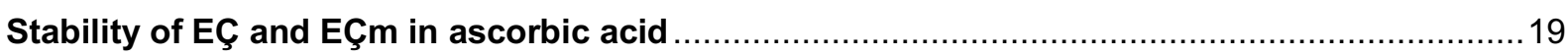

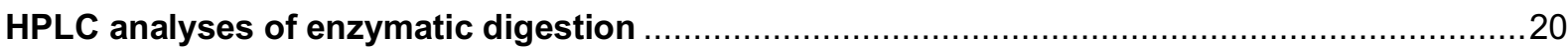

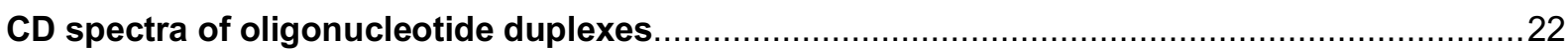

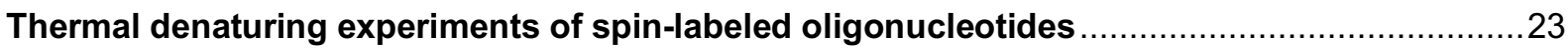

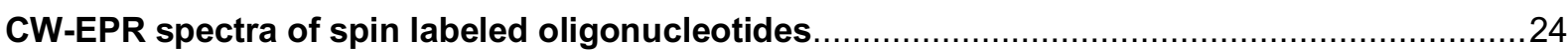

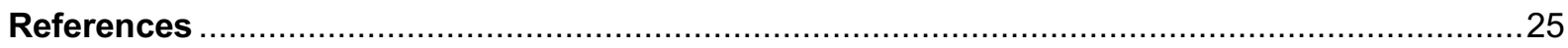


Spin-labeled oligonucleotides and their analysis by MS and EPR spectroscopy. The spin-labeled oligonucleotides prepared are listed in Table S1. The incorporation of EC and EÇm into oligonucleotides was confirmed by HRMS (ESI) analysis. The calculated and observed monoisotopic masses of spin-labeled oligonucleotides are listed in Table S1. The amount of spin labels in each oligonucleotide was determined by spin counting using EPR spectroscopy ${ }^{[1]}$ (Table S1, far right column).

Table S1. Monoisotopic masses and spin-labeling efficiency of spin-labeled oligonucleotides. Oligonucleotides XVII, XVIII and XIX were synthesized with the protected phosphoramidite 14.

\begin{tabular}{|c|c|c|c|c|}
\hline No. & Sequence & $\begin{array}{l}\text { Calculated } \\
\text { Mass }\end{array}$ & $\begin{array}{l}\text { Measured } \\
\text { Mass }\end{array}$ & $\begin{array}{c}\text { Radical } \\
\text { content (\%) }\end{array}$ \\
\hline I & 5'-d(CGCGAATTEÇGCG)-3' & 3904.8 & 3901.2 & 99 \\
\hline II & 5'-d(GACCTCGEÇATCGTG)-3' & 4497.9 & 4494.2 & 96 \\
\hline III & 5'-d(AGTGGAEÇGCTTGGGGTGTA)-3' & 6198.1 & 6192.6 & 82 \\
\hline IV & 5'-d(ATACAEÇCCCAAGCGTCCAC)-3' & 5944.9 & 5939.7 & 81 \\
\hline $\mathbf{V}$ & 5'-d(ATACACEÇCCAAGCGTCCAC)-3' & 5944.9 & 5939.7 & 100 \\
\hline VI & 5'-d(ATACACCEÇCAAGCGTCCAC)-3' & 5944.9 & 5939.7 & 82 \\
\hline VII & 5'-d(ATACACCCEÇAAGCGTCCAC)-3' & 5944.9 & 5939.7 & 94 \\
\hline $\mathbf{X V I}$ & 5'-d(CACGATGCGAGGTC)-3' & 4288.8 & 4285.1 & \\
\hline VIII & 5'-d(CGCGAATTCGCG)-3' & 3646.4 & 3643.1 & \\
\hline $\mathbf{I X}$ & 5'-d(GACCTCGCATCGTG)-3' & 4239.8 & 4236.1 & \\
\hline $\mathbf{X}$ & 5'-d(AGTGGACGCTTGGGGTGTA)-3' & 5939.9 & 5934.6 & \\
\hline $\mathbf{X I}$ & 5'-d(ATACACCCCAAGCGTCCAC)-3' & 5686.7 & 5682.0 & \\
\hline XII & 5'-AGUGGAEÇmGCUUGUGGGGUGUA-3' & 7097.1 & 7056.5 & 52 \\
\hline XIII & 5'-AUACAEÇmCCCACAAGCGUCCAC-3' & 6869.1 & 6863.6 & 71 \\
\hline XIV & 5'-AUACACEÇmCCACAAGCGUCCAC-3' & 6869.1 & 6863.6 & 98 \\
\hline $\mathbf{X V}$ & 5'-AUACACCEÇmCACAAGCGUCCAC-3' & 6869.1 & 6860.6 & 64 \\
\hline $\mathbf{X V I}$ & 5'-AUACACCCEÇmACAAGCGUCCAC-3' & 6869.1 & 6863.6 & 94 \\
\hline XVII & 5'-AGUGGAEÇmGCUUGUGGGGUGUA-3' & 7097.1 & 7096.5 & 99 \\
\hline XVIII & 5'-AUACAEÇmCCCACAAGCGUCCAC-3' & 6869.1 & 6863.6 & 100 \\
\hline $\mathbf{X I X}$ & 5'-AUACACCEÇmCACAAGCGUCCAC-3' & 6869.1 & 6863.6 & 98 \\
\hline $\mathbf{X X}$ & 5'-AGUGGACGCUUGUGGGGUGUA-3' & 6825.1 & 6819.4 & \\
\hline $\mathbf{X X I}$ & 5'-AUACACCCCACAAGCGUCCAC-3' & 6597.09 & 6591.5 & \\
\hline
\end{tabular}


${ }^{1} \mathrm{H}-,{ }^{13} \mathrm{C}$ - and ${ }^{31} \mathrm{P}$-NMR spectra

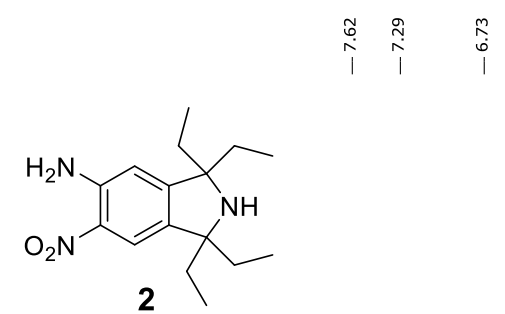

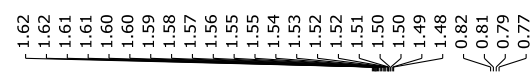



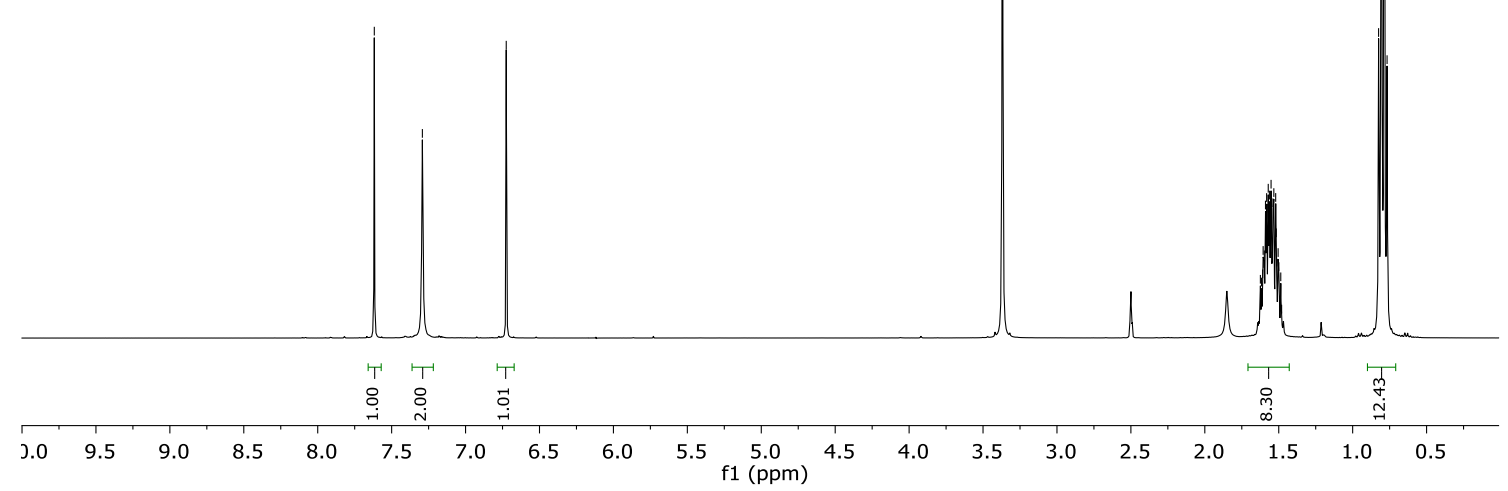

Figure S1. ${ }^{1} \mathrm{H}-\mathrm{NMR}$ spectrum of 2.







Figure S3. ${ }^{1} \mathrm{H}-\mathrm{NMR}$ spectrum of 3.

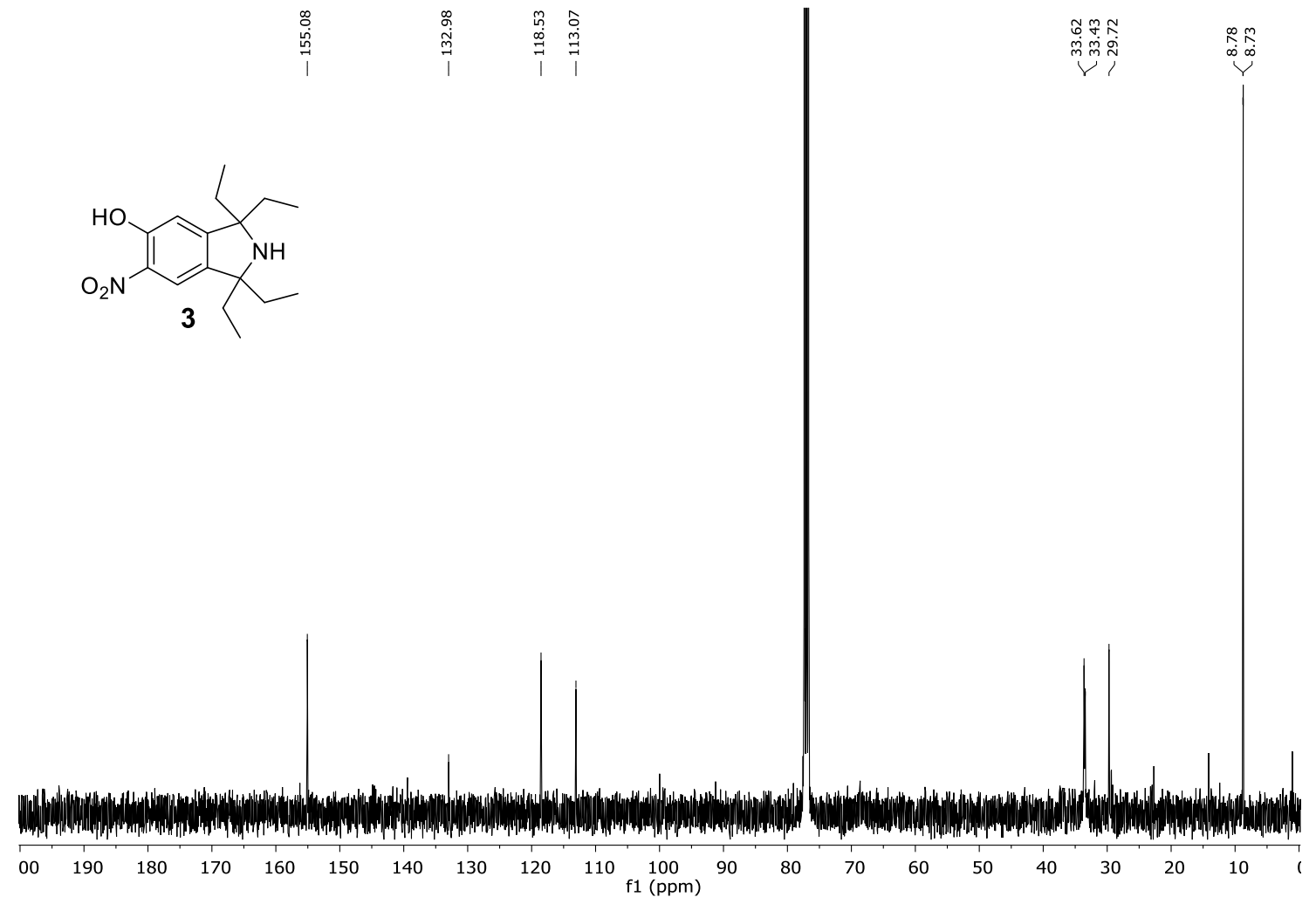

Figure S4. ${ }^{13} \mathrm{C}-\mathrm{NMR}$ spectrum of 3 . 




Figure S5. ${ }^{1} \mathrm{H}-\mathrm{NMR}$ spectrum of 4. 


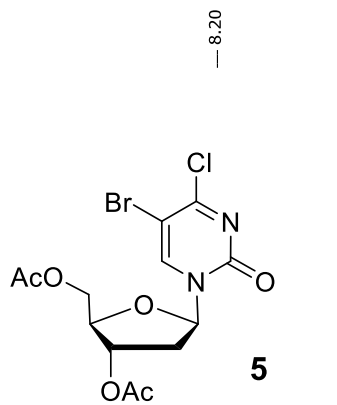

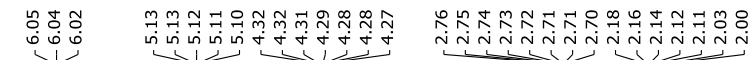

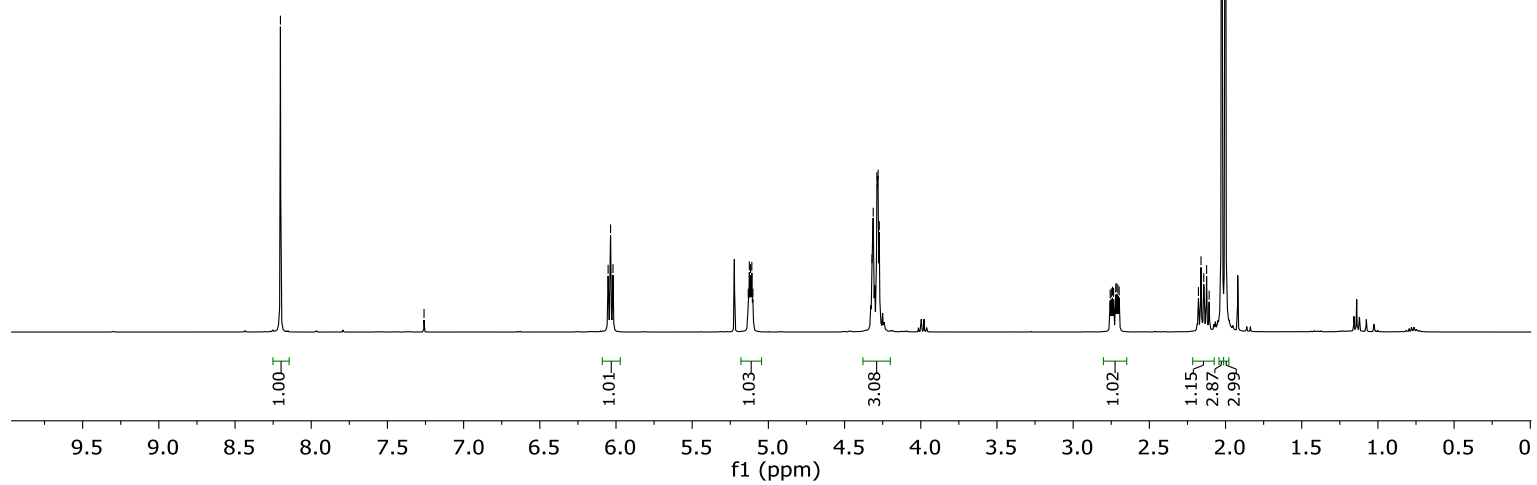

Figure S6. ${ }^{1} \mathrm{H}-\mathrm{NMR}$ spectrum of 5.

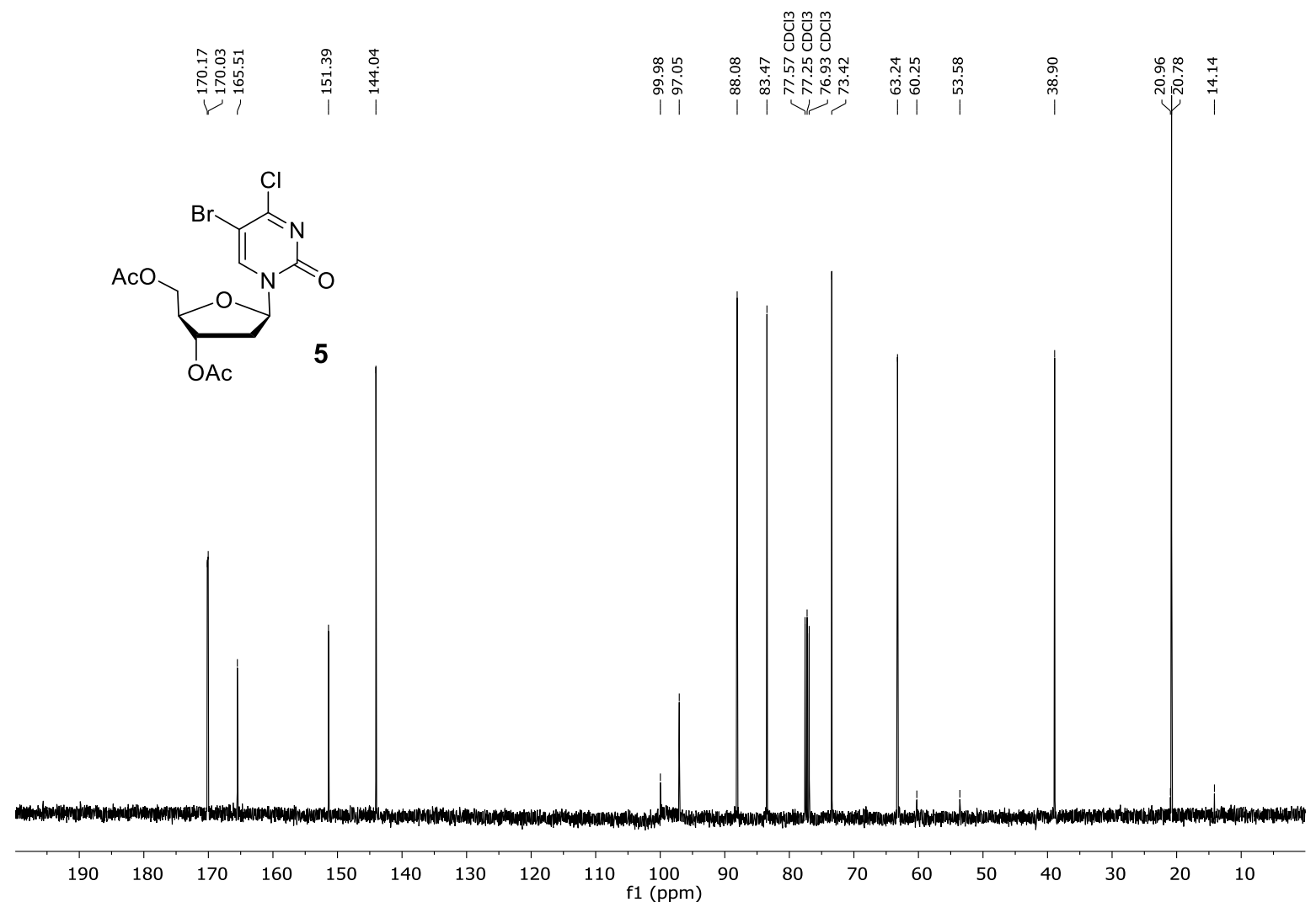

Figure $\mathbf{S 7} .{ }^{13} \mathrm{C}-\mathrm{NMR}$ spectrum of $\mathbf{5}$. 


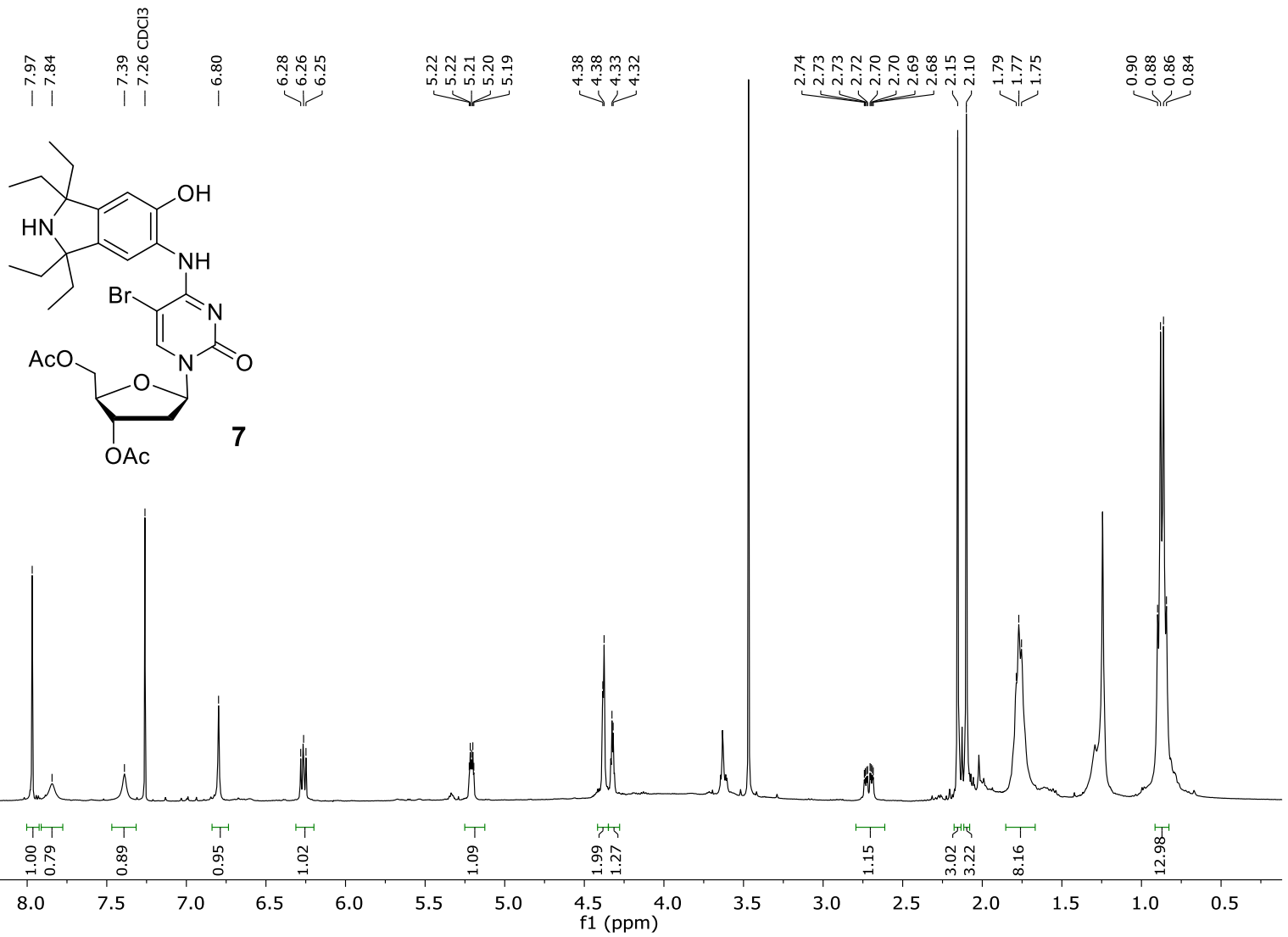

Figure S8. ${ }^{1} \mathrm{H}-\mathrm{NMR}$ spectrum of 7.

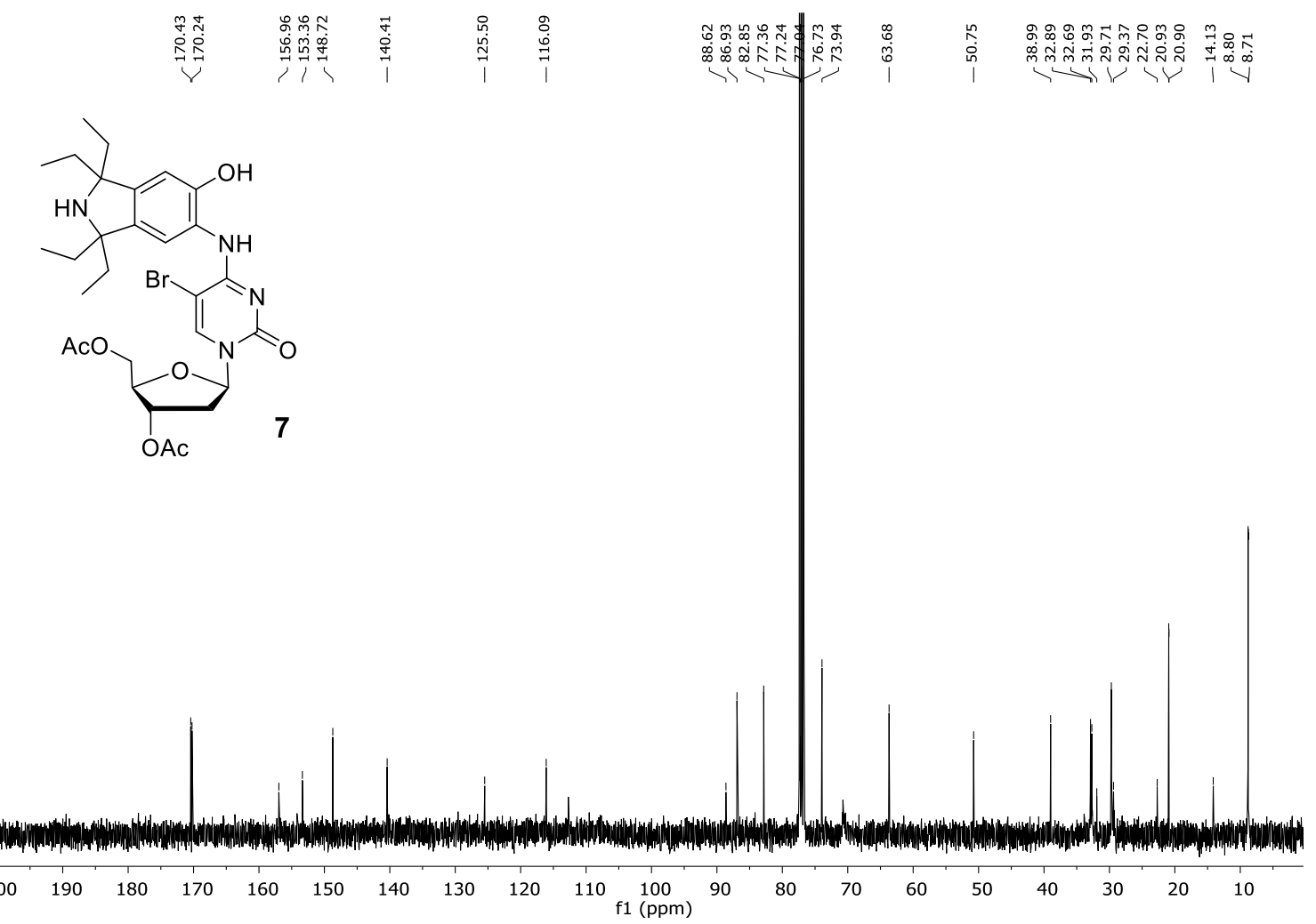

Figure S9. ${ }^{13} \mathrm{C}-\mathrm{NMR}$ spectrum of 7. 


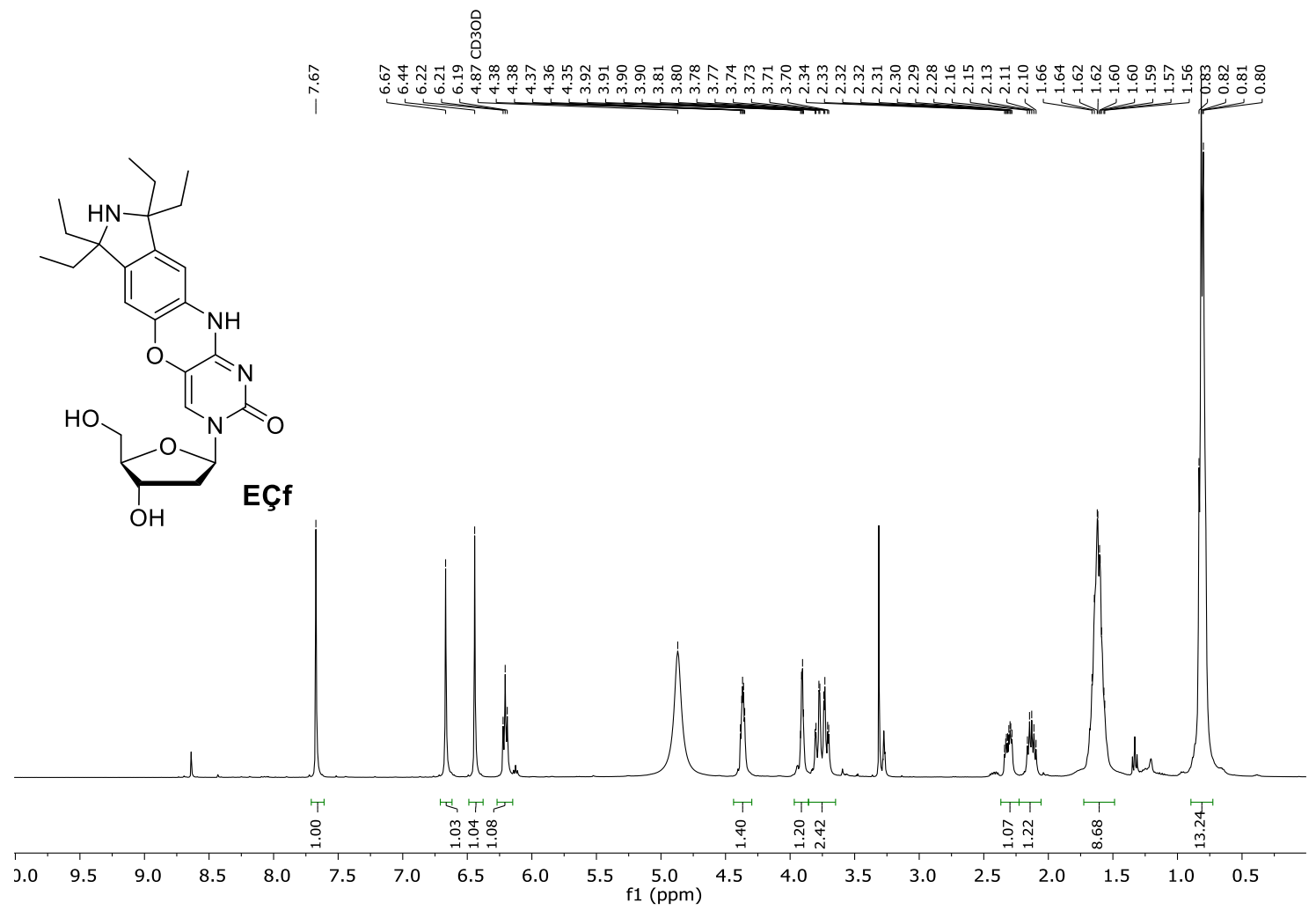

Figure S10. 1H-NMR spectrum of EÇf.

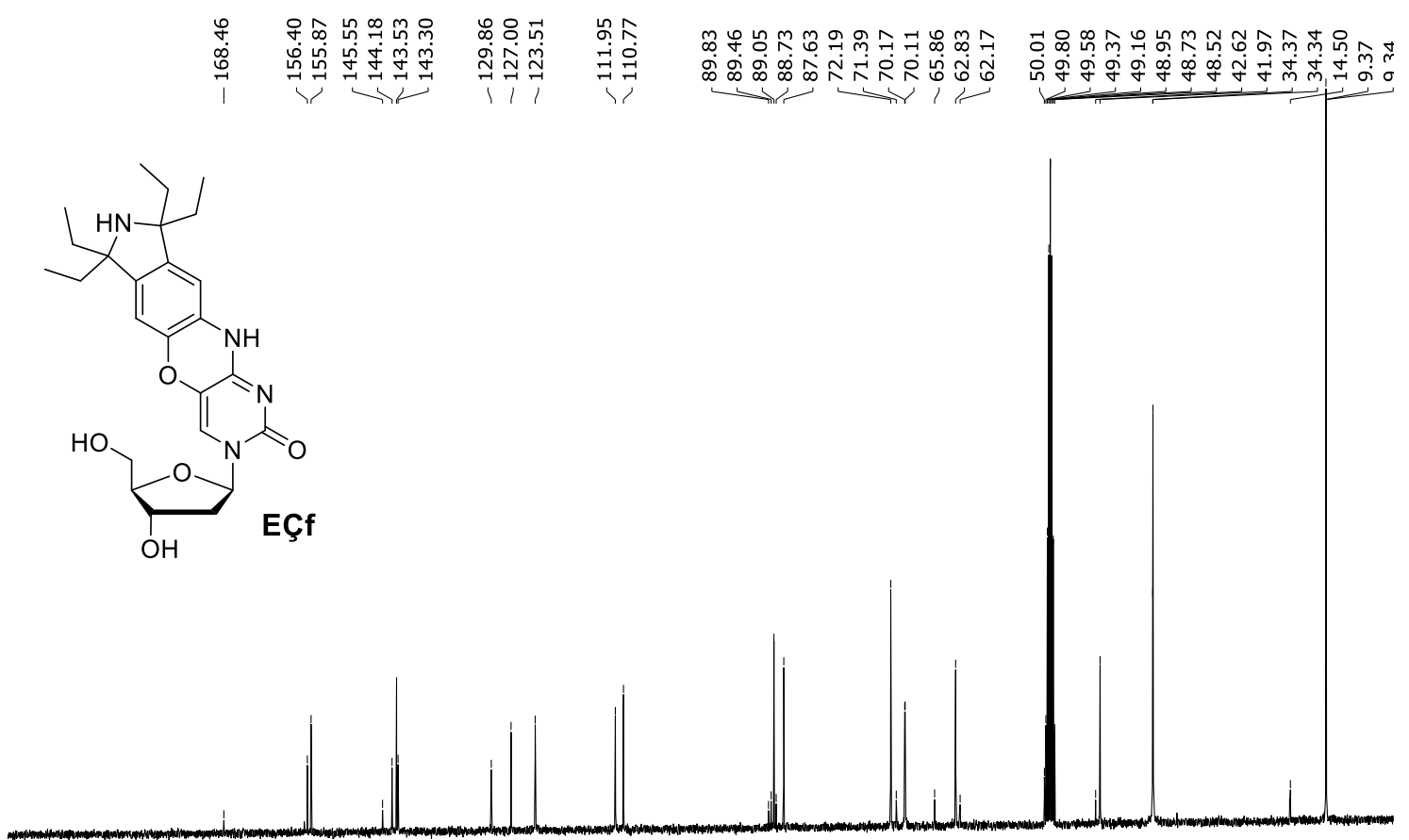

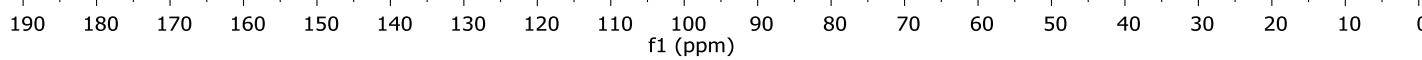

Figure S11. ${ }^{13} \mathrm{C}-\mathrm{NMR}$ spectrum of EÇf. 


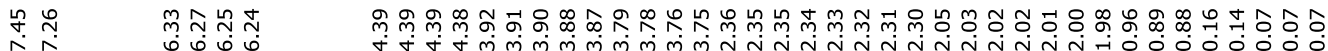
l.<smiles>CCCOC1CC(n2cc3oc4cc5c(cc4c3nc2=O)C(CC)(CC)NC5(CC)CC)OC1(CC)CC</smiles>

TBDMS-EÇf

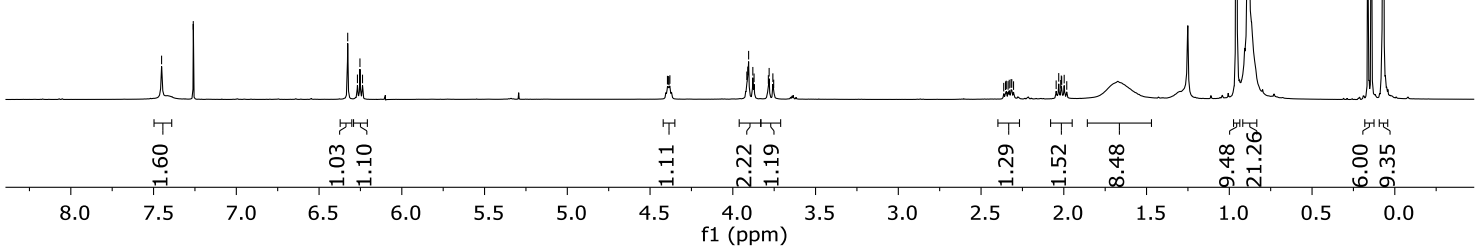

Figure S12. ${ }^{1} \mathrm{H}-\mathrm{NMR}$ spectrum of TBDMS-EÇf.

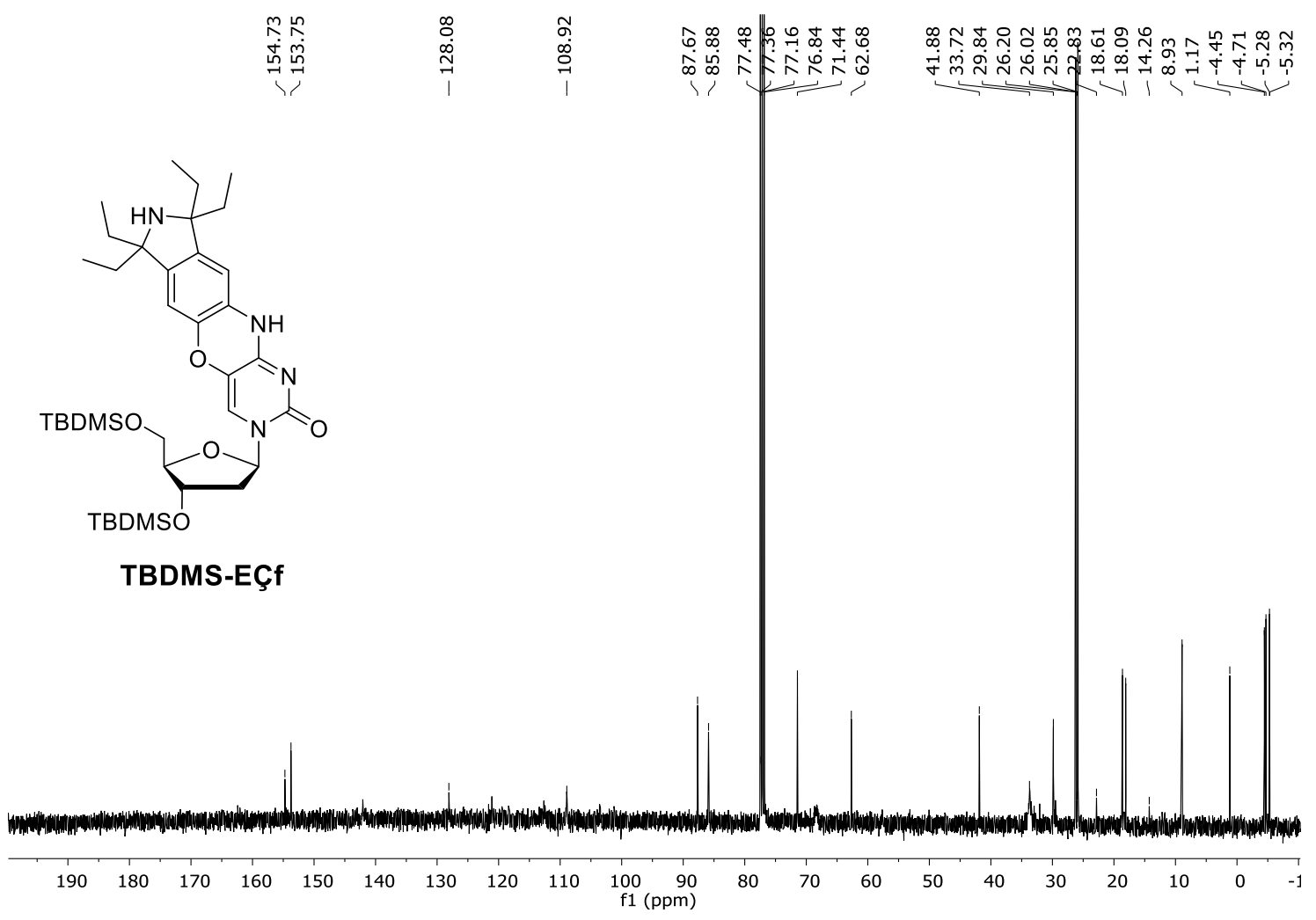

Figure S13. ${ }^{13} \mathrm{C}-\mathrm{NMR}$ spectrum of TBDMS-EÇf. 


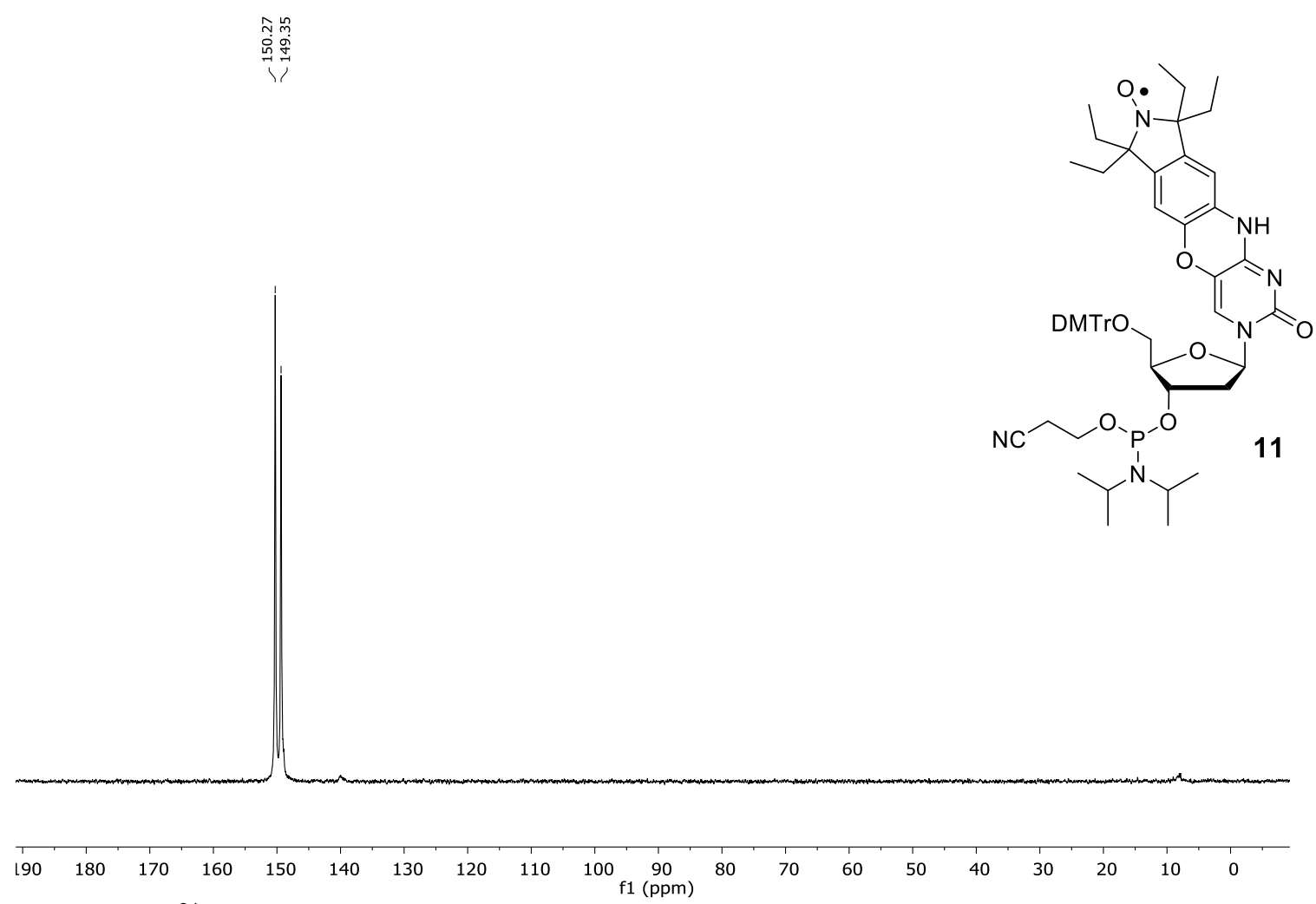

Figure S14. ${ }^{31} \mathrm{P}-\mathrm{NMR}$ spectrum of phosphoramidite 11. 


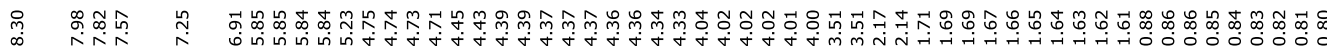<smiles>CCC1(CC)NC(CC)(CC)c2cc(Nc3nc(=O)n(C4OC(C)C(OC(C)=O)C4OC(C)=O)cc3Br)c(O)cc21</smiles>

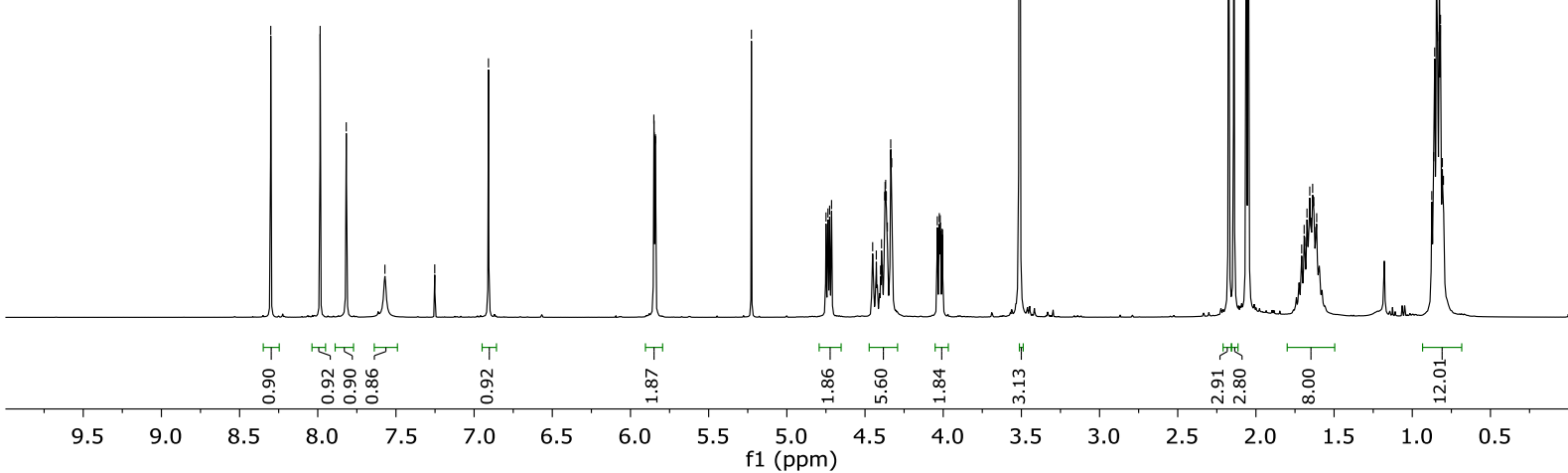

Figure S15. ${ }^{1} \mathrm{H}-\mathrm{NMR}$ spectrum of 8.



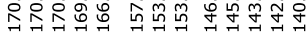

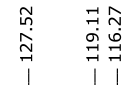

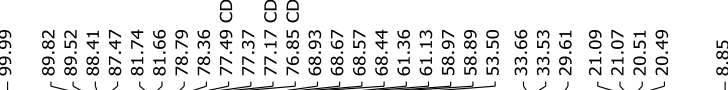

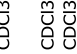<smiles>CCC1(CC)NC(CC)(CC)c2cc(Nc3nc(=O)n(C4OC(CO)C(OC(C)=O)C4OCCOC)cc3Br)c(O)cc21</smiles>

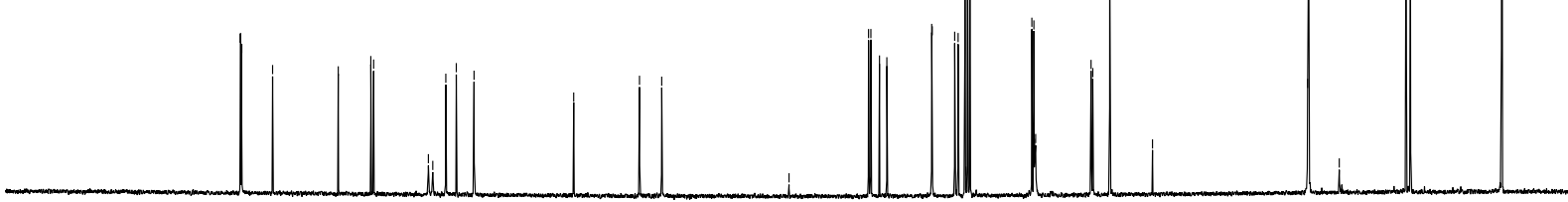



Figure S16. ${ }^{13} \mathrm{C}-\mathrm{NMR}$ spectrum of 8. 




Figure S17. ${ }^{1} \mathrm{H}-\mathrm{NMR}$ spectrum of EÇmf.

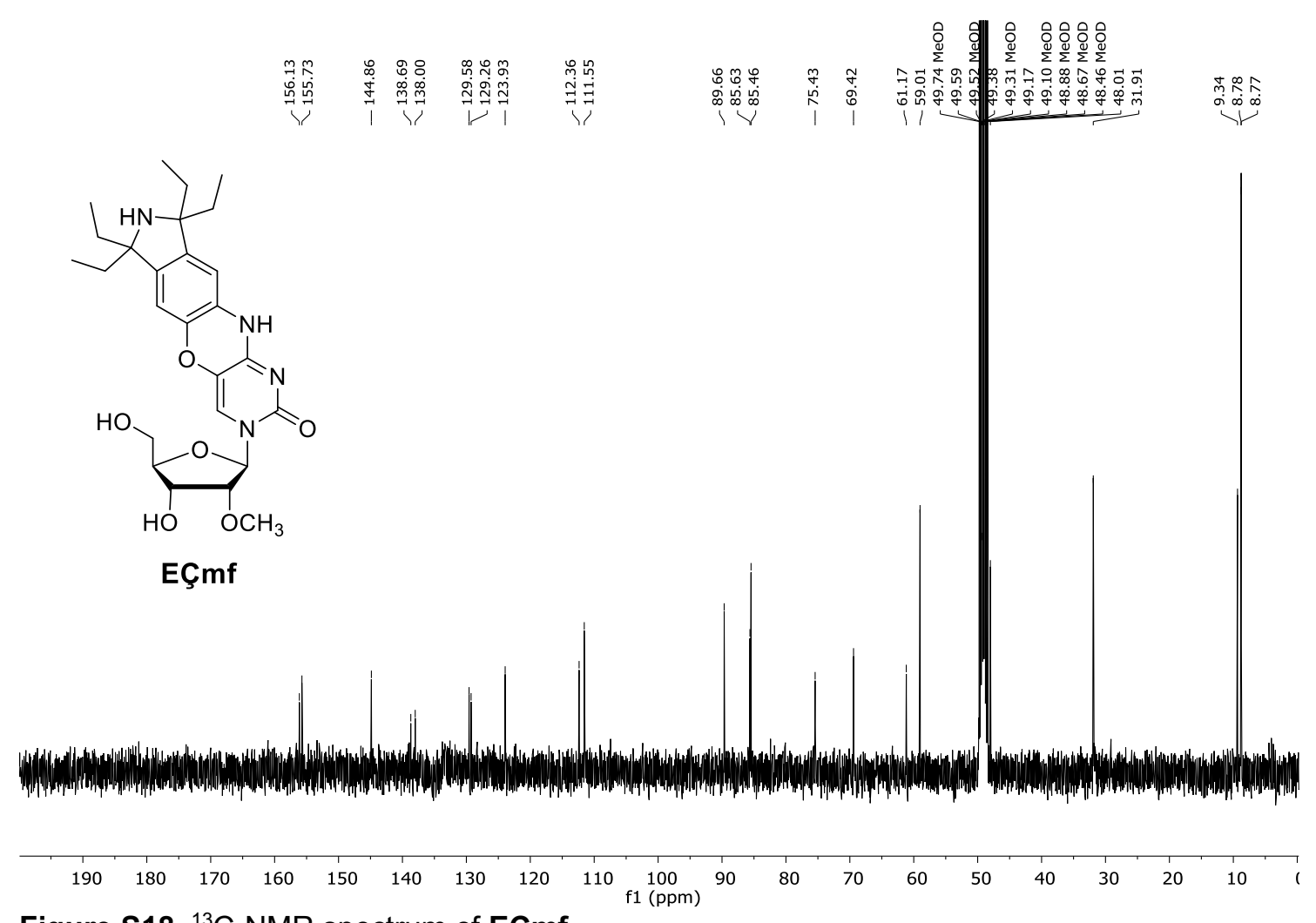

Figure S18. ${ }^{13} \mathrm{C}-\mathrm{NMR}$ spectrum of EÇmf. 


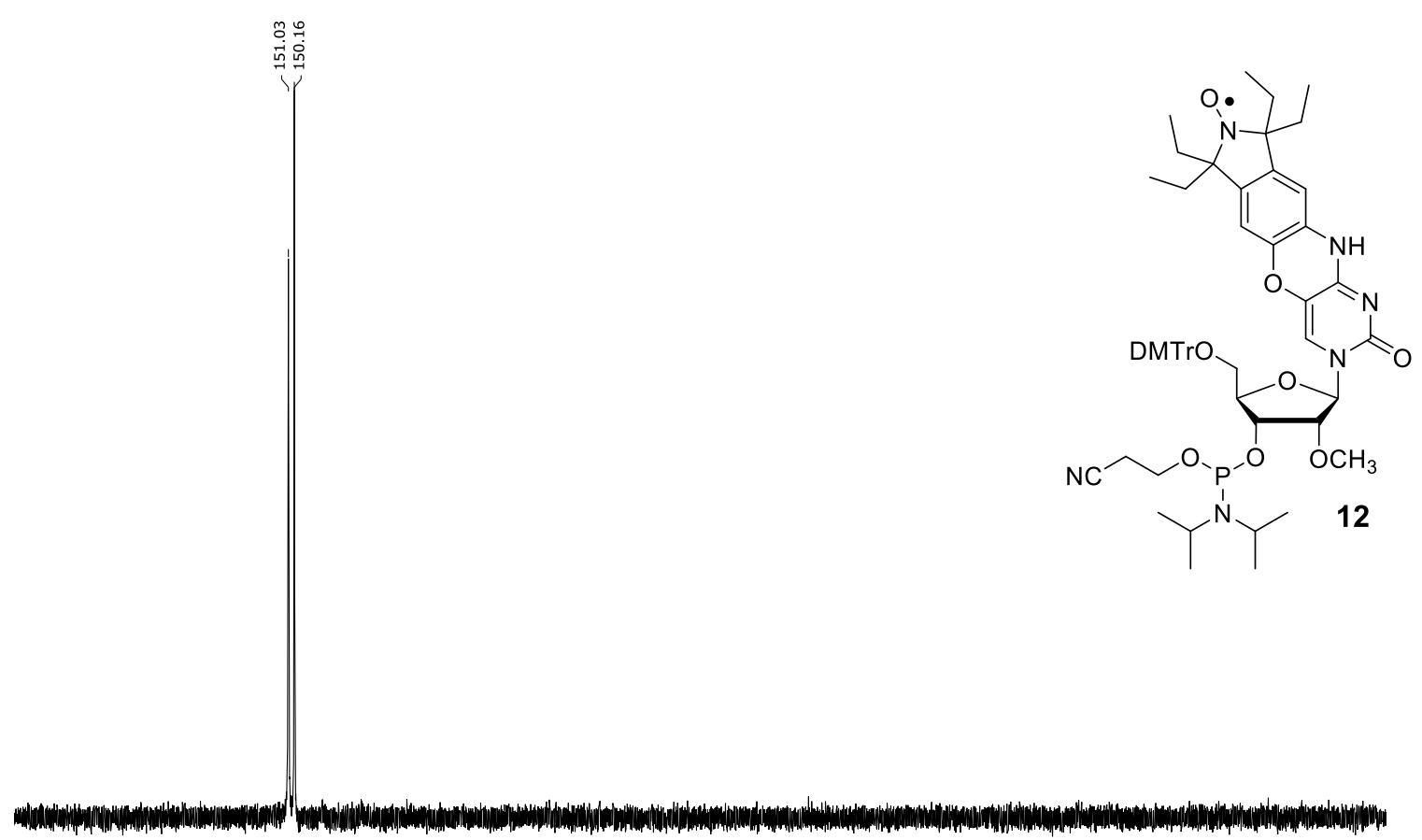

\begin{tabular}{llllllllllllllllllll}
\hline 90 & 180 & 170 & 160 & 150 & 140 & 130 & 120 & 110 & 100 & 90 & 80 & 70 & 60 & 50 & 40 & 30 & 20 & 10 & 0
\end{tabular}

Figure S19. ${ }^{31} \mathrm{P}-\mathrm{NMR}$ spectrum of phosphoramidite 12. 


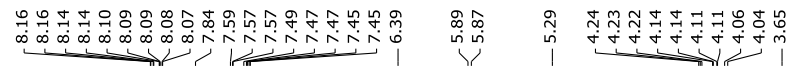

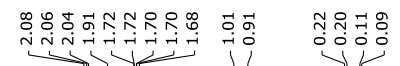
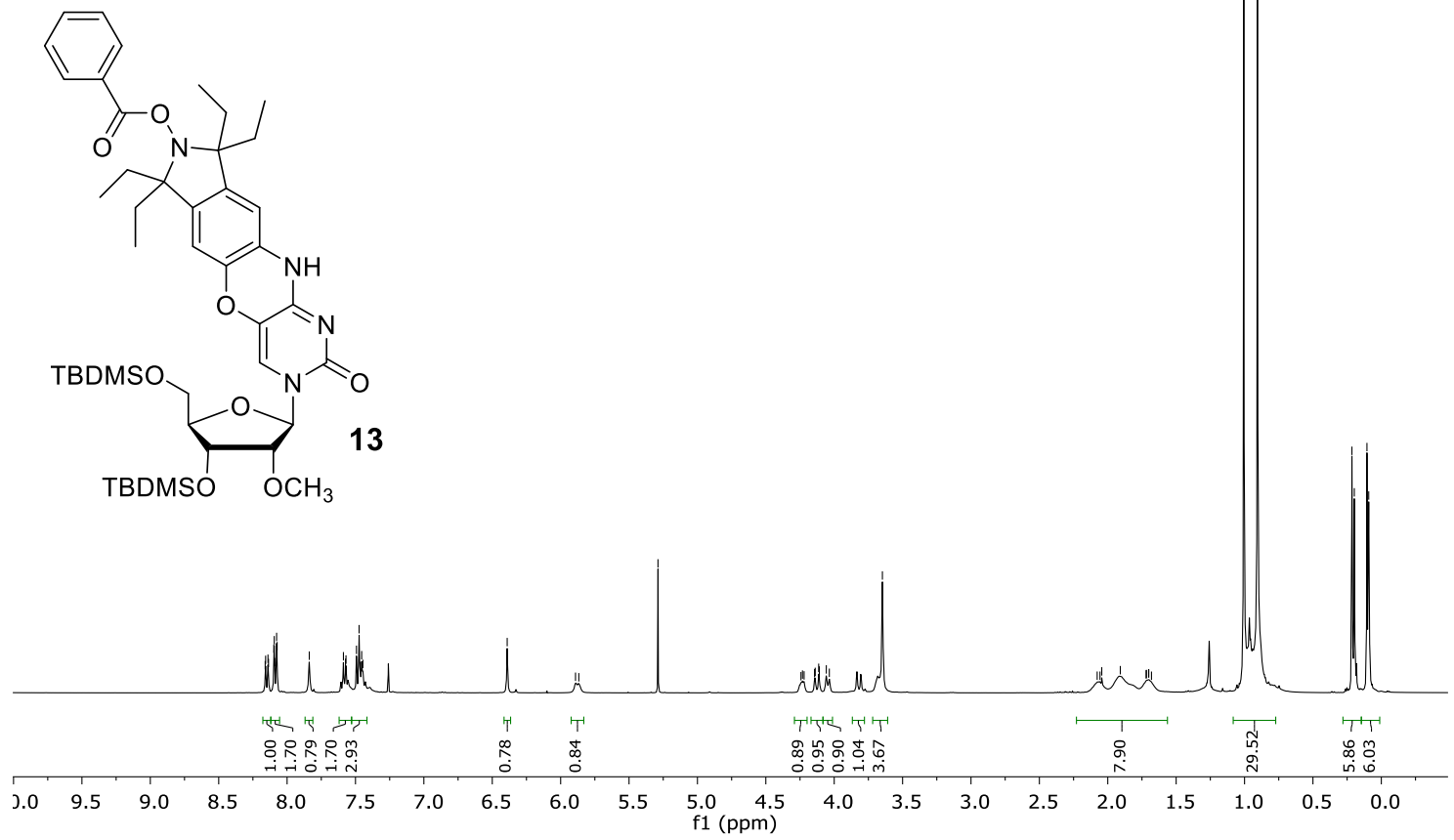

Figure S20. ${ }^{1} \mathrm{H}-\mathrm{NMR}$ spectrum of 13.

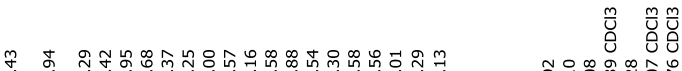

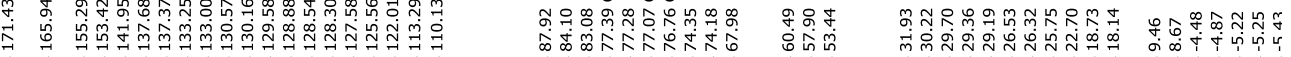

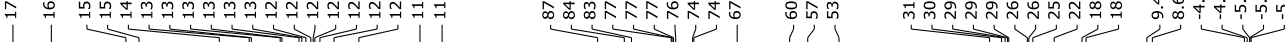

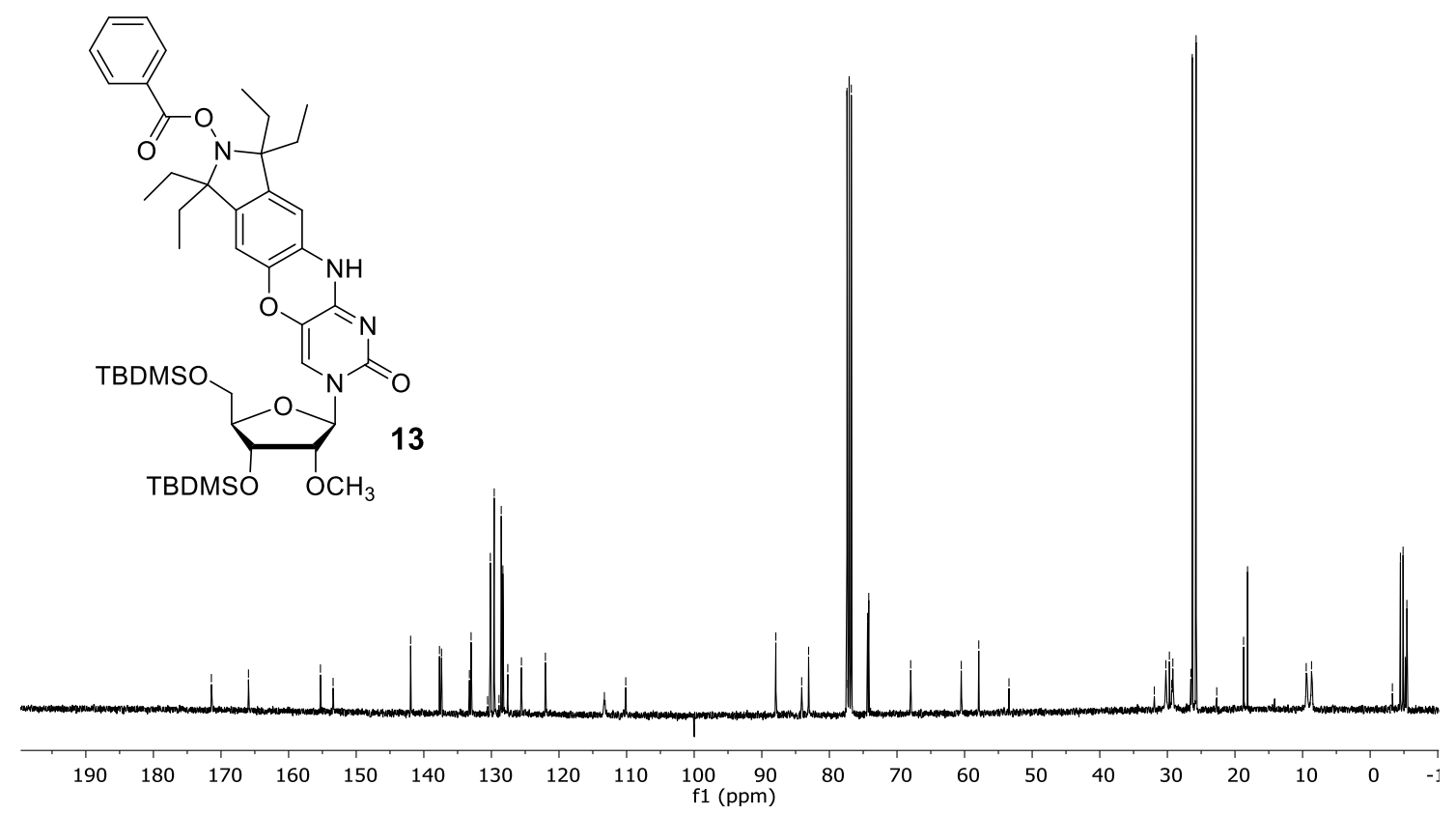

Figure S21. ${ }^{13} \mathrm{C}-\mathrm{NMR}$ spectrum of 13. 


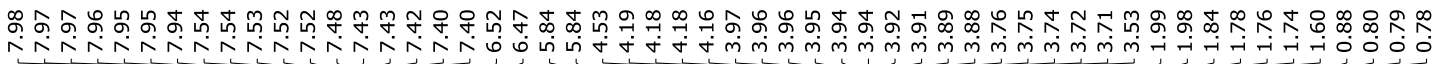

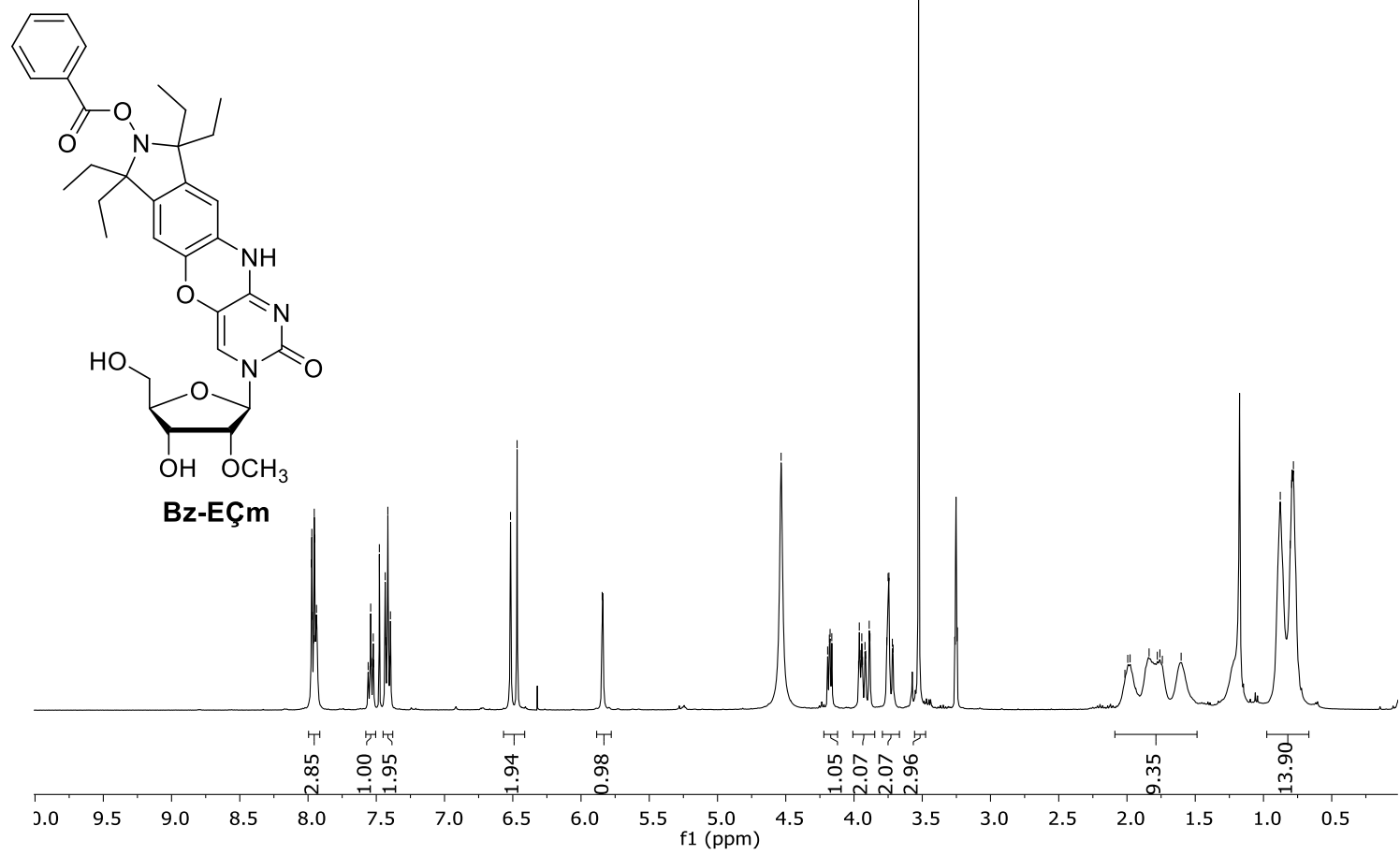

Figure S22. ${ }^{1} \mathrm{H}-\mathrm{NMR}$ spectrum of Bz-EÇm.

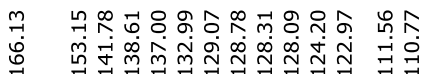

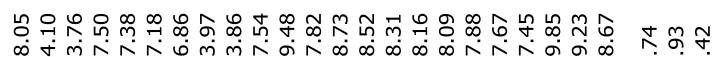

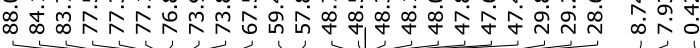

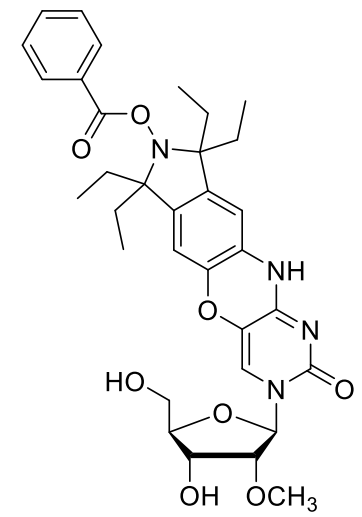

Bz-EÇm



$\begin{array}{lllllllllll}190 & 180 & 170 & 160 & 150 & 140 & 130 & 120 & 110 & \begin{array}{c}100 \\ \mathrm{f} 1(\mathrm{ppm})\end{array}\end{array}$

Figure S23. ${ }^{13} \mathrm{C}-\mathrm{NMR}$ spectrum of Bz-EÇm. 


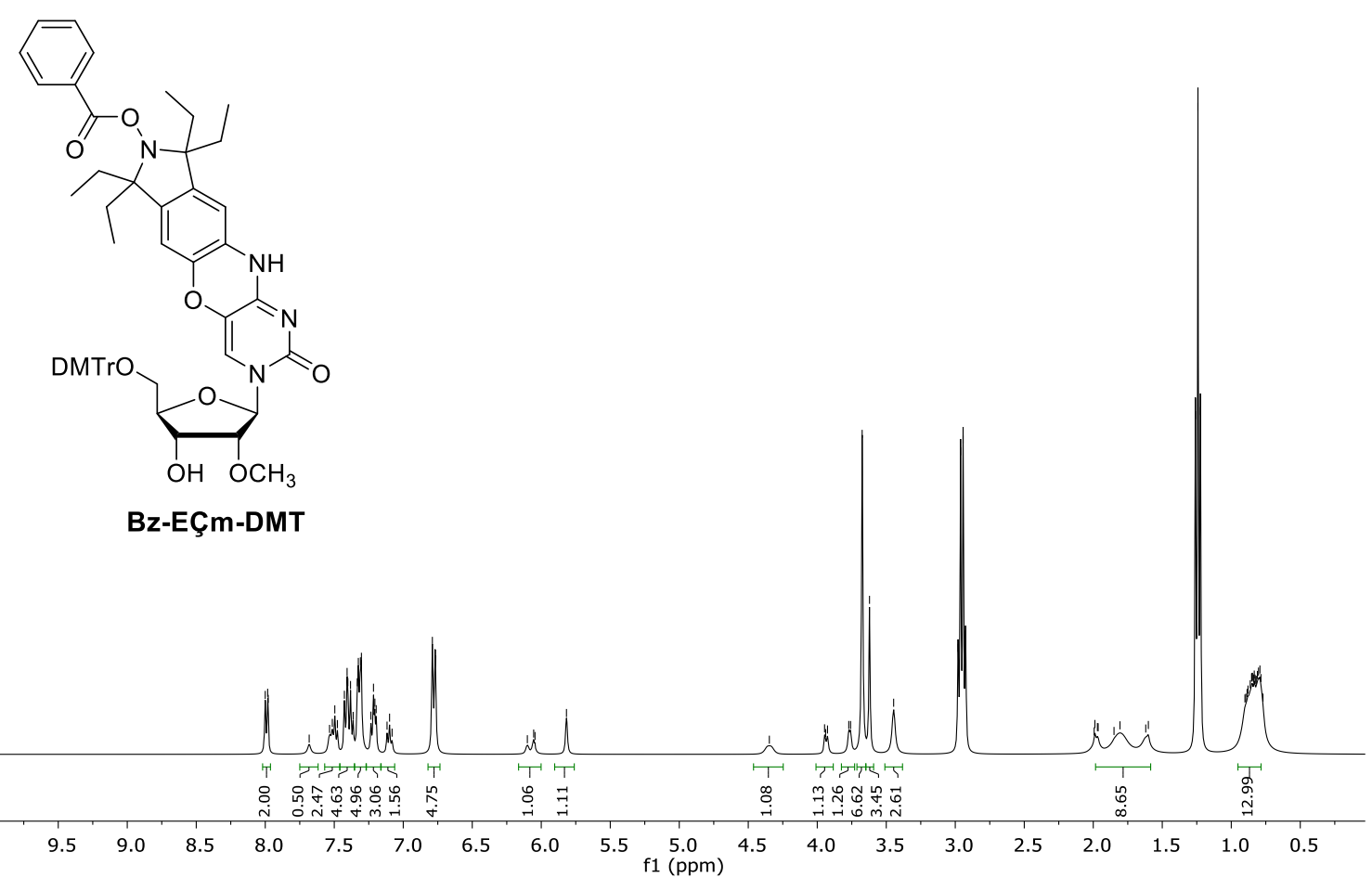

Figure S24. ${ }^{1} \mathrm{H}-\mathrm{NMR}$ spectrum of Bz-EÇm-DMT.

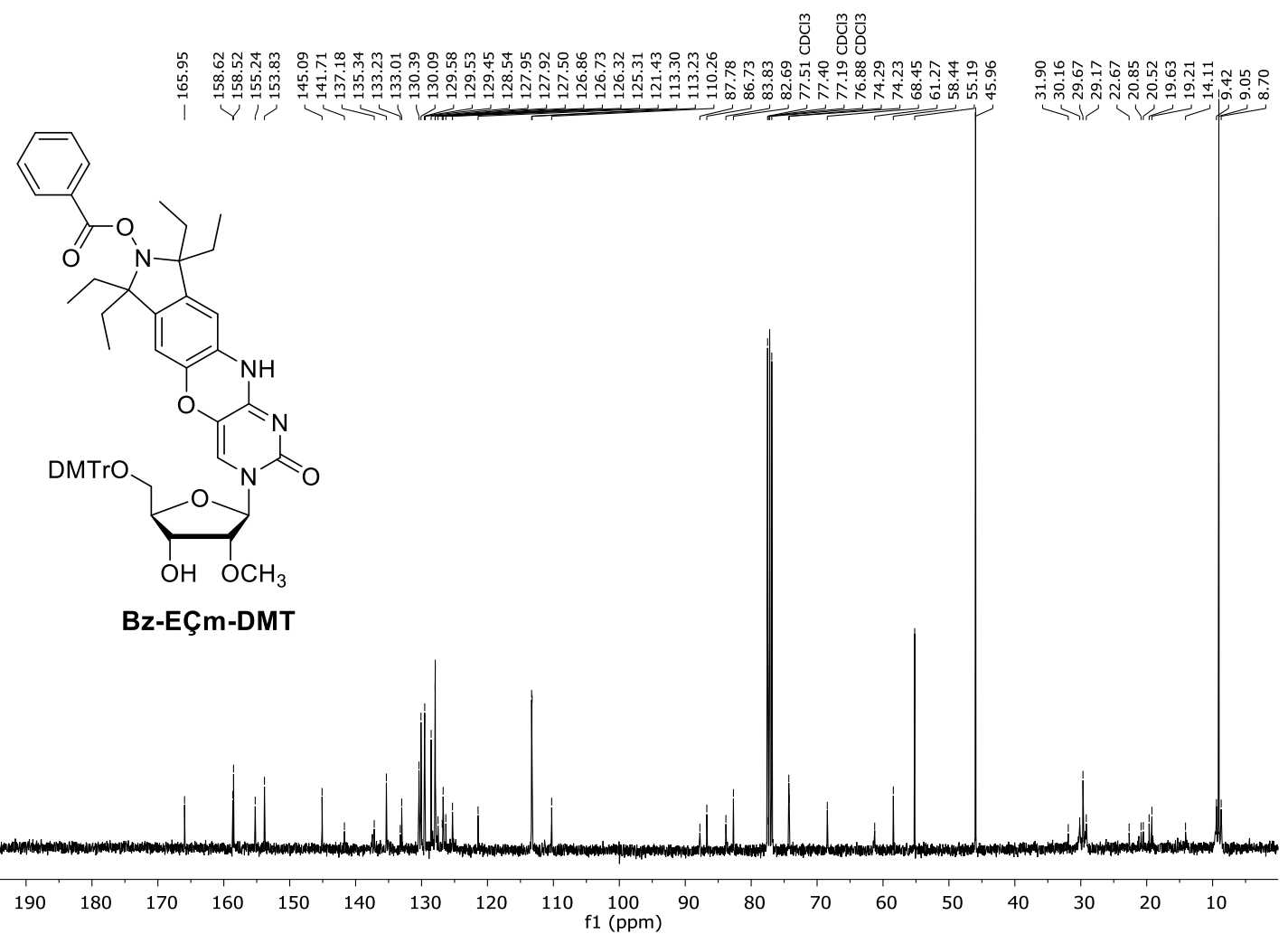

Figure S25. ${ }^{13} \mathrm{C}-\mathrm{NMR}$ spectrum of Bz-EÇm-DMT. 






Figure S26. ${ }^{1} \mathrm{H}-\mathrm{NMR}$ spectrum of 14.

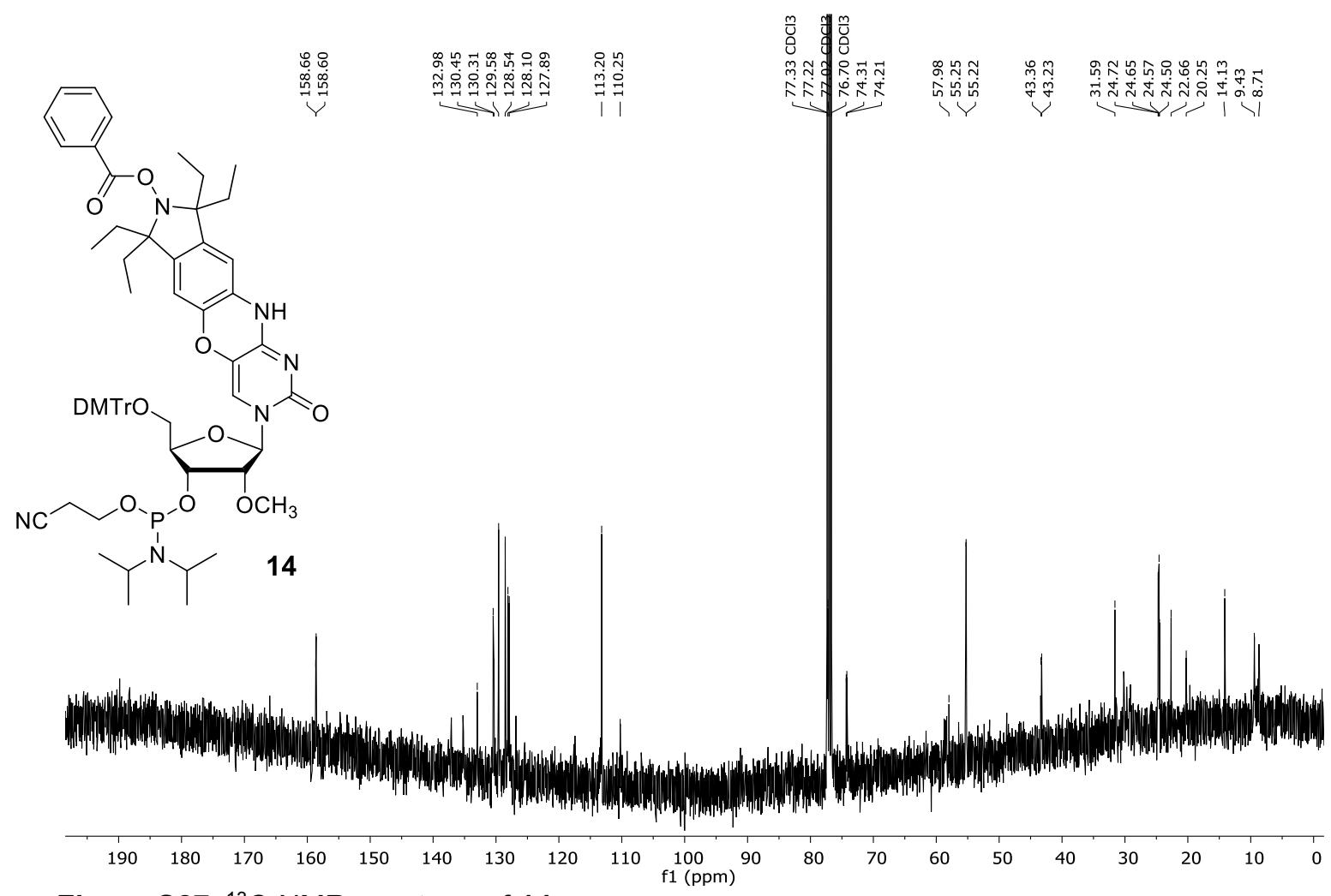

Figure S27. ${ }^{13} \mathrm{C}-\mathrm{NMR}$ spectrum of 14. 


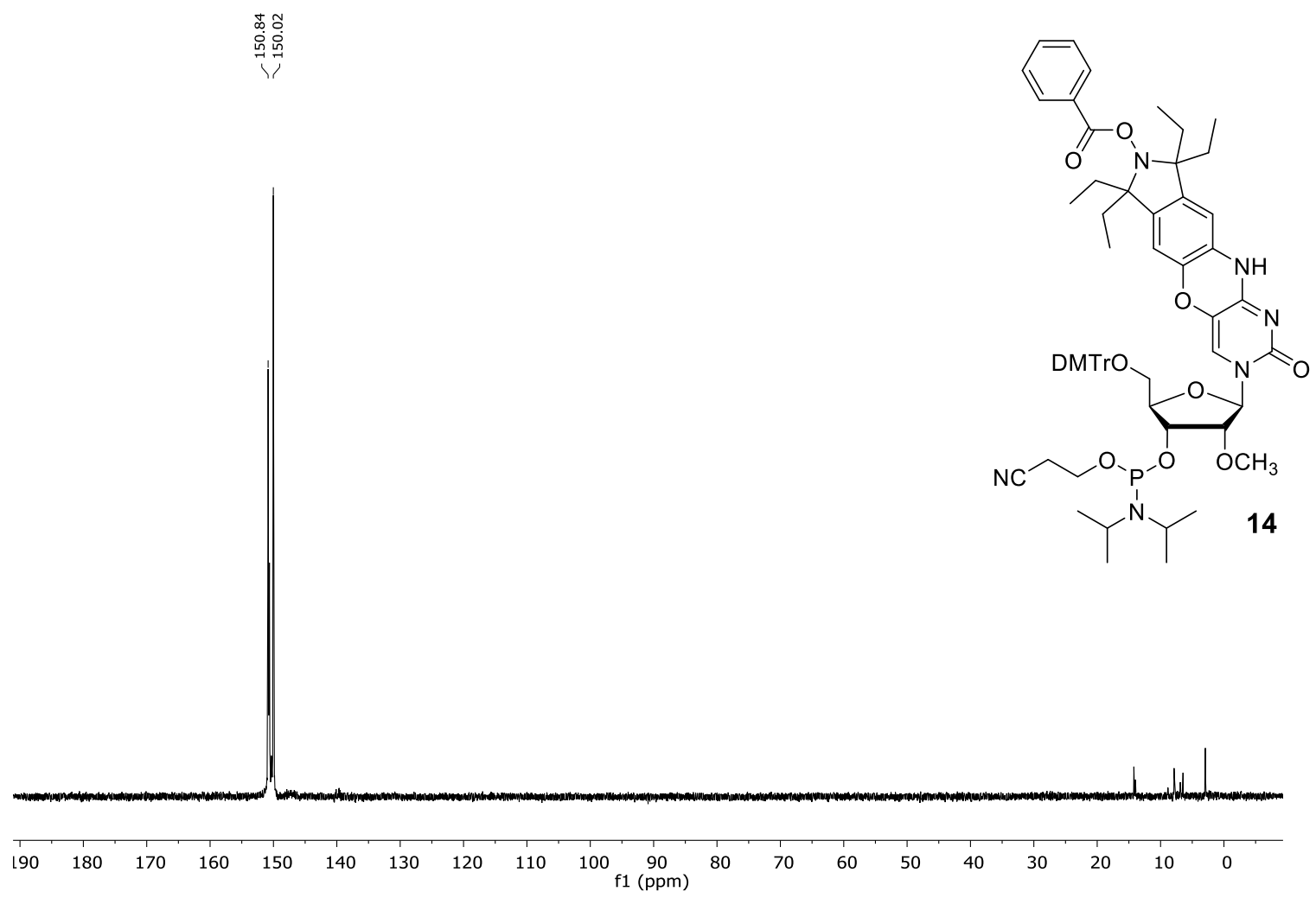

Figure S28. ${ }^{31} \mathrm{P}-\mathrm{NMR}$ spectrum of phosphoramidite 14. 


\section{Stability of EÇ and EÇm in ascorbic acid}

The stability of EÇ, EÇm, EÇ-labeled DNA, and EÇm-labeled RNA in the presence of ascorbate was determined in the following manner. Each sample was dissolved in a solution of ascorbic acid $(200 \mu \mathrm{M}$ nitroxide, $5 \mathrm{mM}$ ascorbic acid, $10 \mathrm{mM}$ phosphate, $100 \mathrm{mM} \mathrm{NaCl}, 0.1 \mathrm{mM} \mathrm{Na} 2 \mathrm{EDTA}, \mathrm{pH}$ 7.0, $10 \mu \mathrm{L}$ ) by immediate vortexing, followed by a brief centrifugation, placement in an EPR tube that was sealed in both ends and placed in the spectrometer. The first measurement was immediately performed, and subsequent measurements performed at set time-intervals. The parameters on the EPR spectrometer were as follows: B0: $337.0 \mathrm{mT}$; range: $12 \mathrm{mT}$; sweep time: $30 \mathrm{~s}$; smooth: $0.1 \mathrm{~s}$; NOPs: 4096; number of passes: 1 . The temperature was set to $22^{\circ} \mathrm{C}$ throughout the measurement. The EPR signal decay was subsequently plotted as a function of time (Figures 5 and S29).

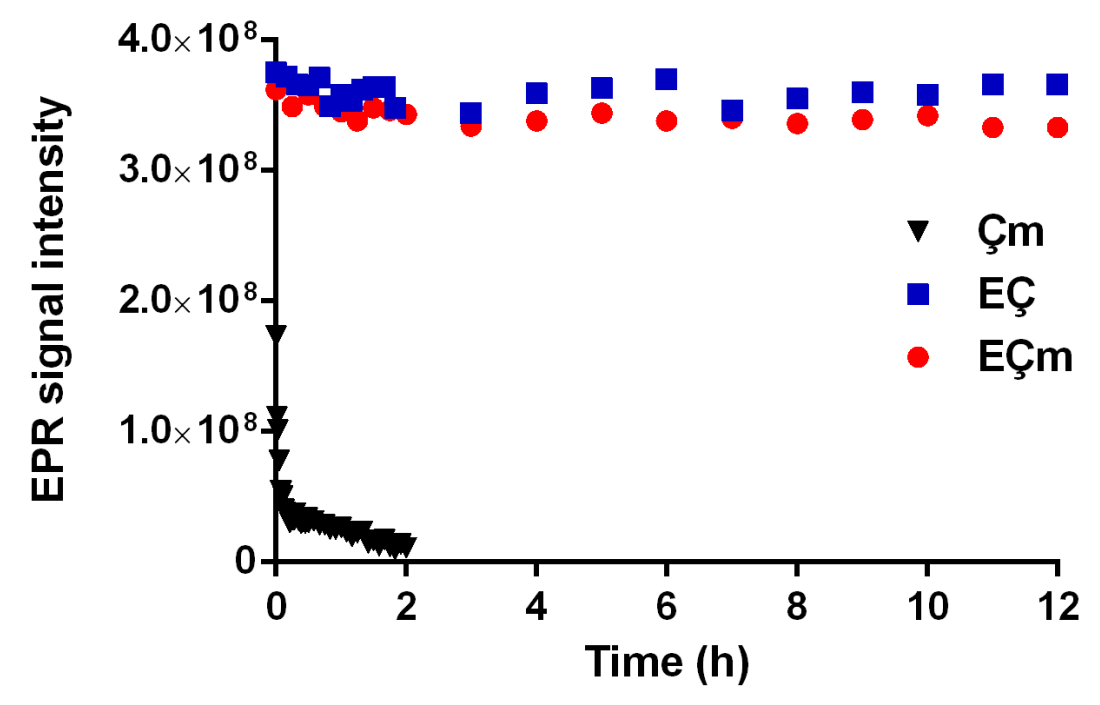

Figure S29. Stability of EÇ, EÇm and Çm in ascorbic acid (200 $\mu \mathrm{M}$ conc. of radical and $5 \mathrm{mM}$ ascorbic acid in PDB buffer $\mathrm{pH}:$ 7.0). The EPR signal intensity is plotted as a function of time. 


\section{HPLC analyses of enzymatic digestion}

A

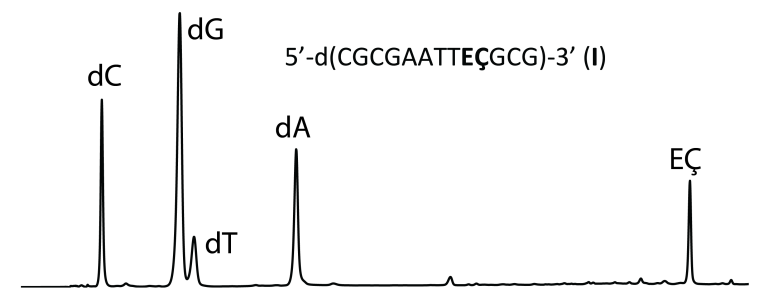

C

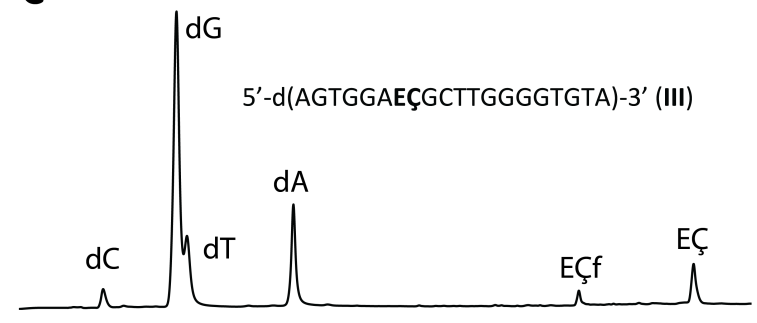

$\mathbf{E}$

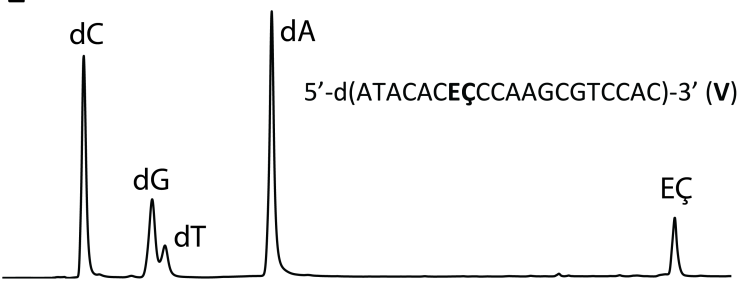

G



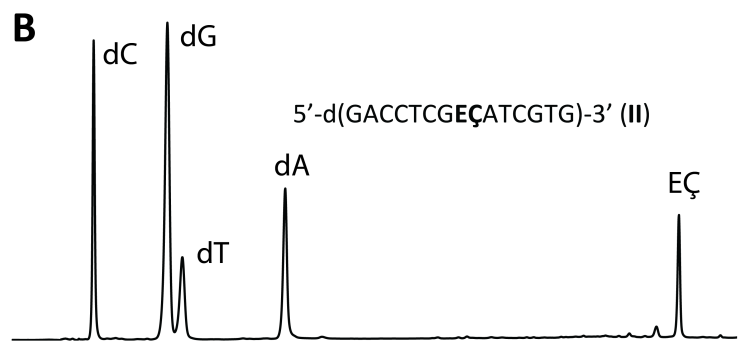

D

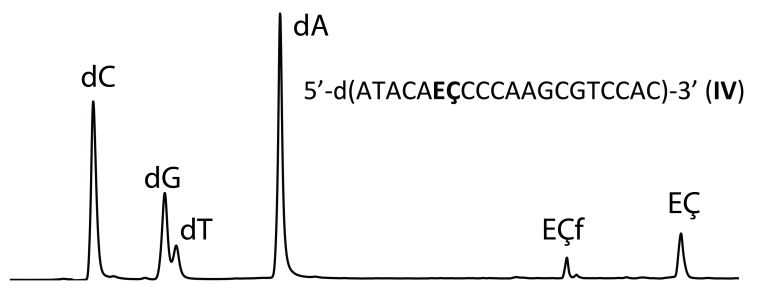

$\mathbf{F}$

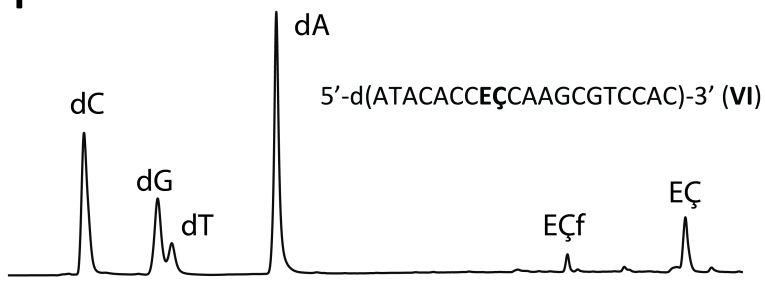

Figure S30. HPLC chromatograms of DNA oligonucleotides after enzymatic digestion with snake venom phosphodiesterase, nuclease $\mathrm{P} 1$, and alkaline phosphatase. ${ }^{[1-2]}$ 
A

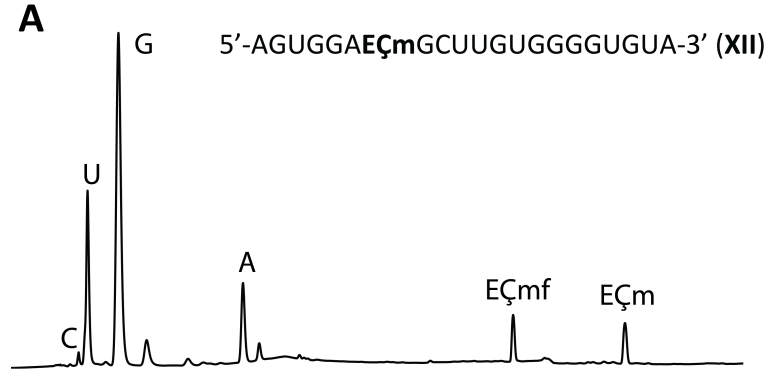

C
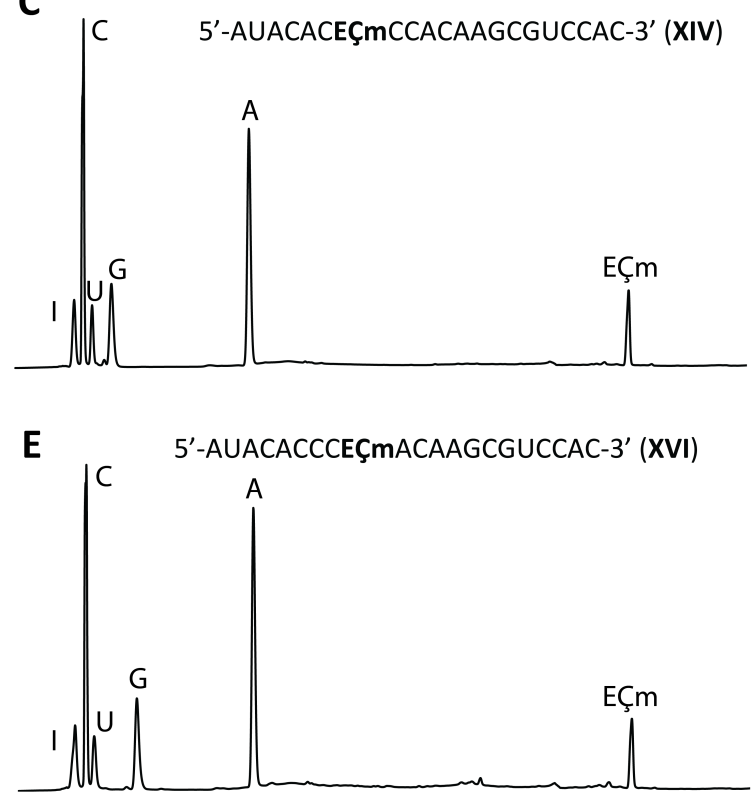

G

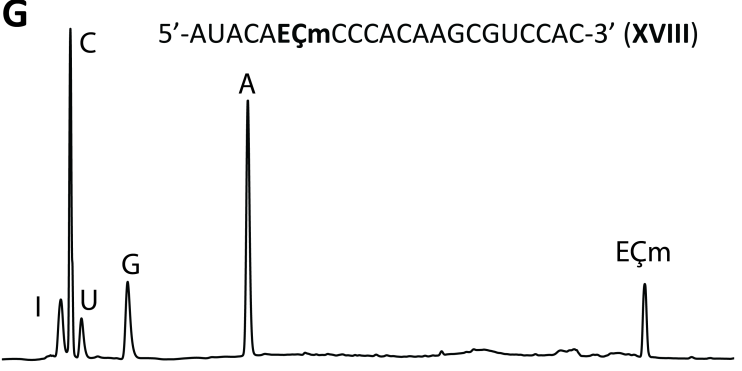

B

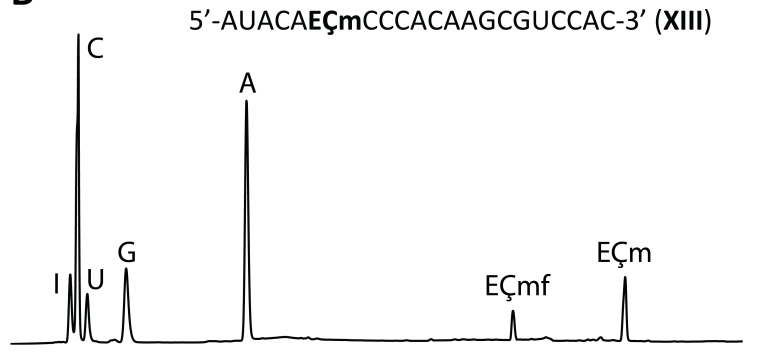

D

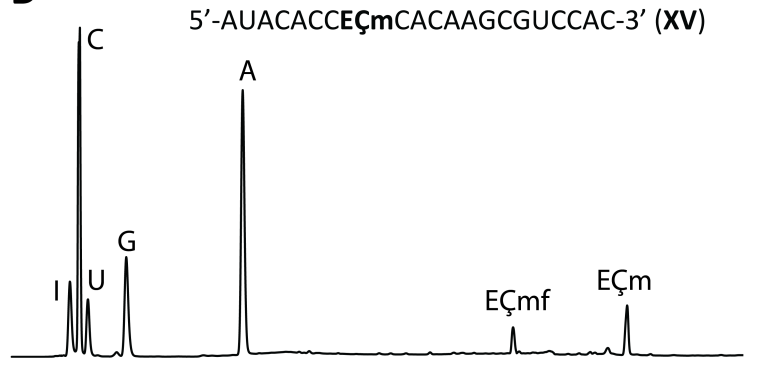

$\mathbf{F}$

5'-AGUGGAEÇmGCUUGUGGGGUGUA-3' (XVII)

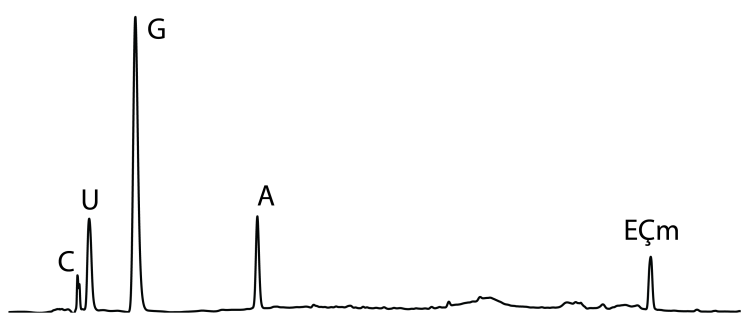

H

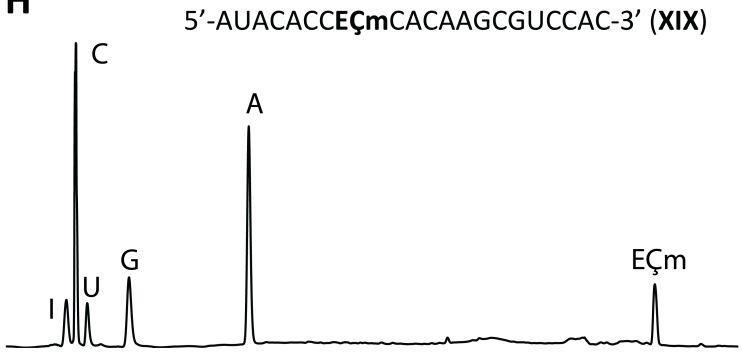

Figure S31. HPLC chromatograms of RNA oligonucleotides after enzymatic digestion with snake venom phosphodiesterase, nuclease $\mathrm{P} 1$, and alkalinephosphatase. 
CD spectra of oligonucleotide duplexes
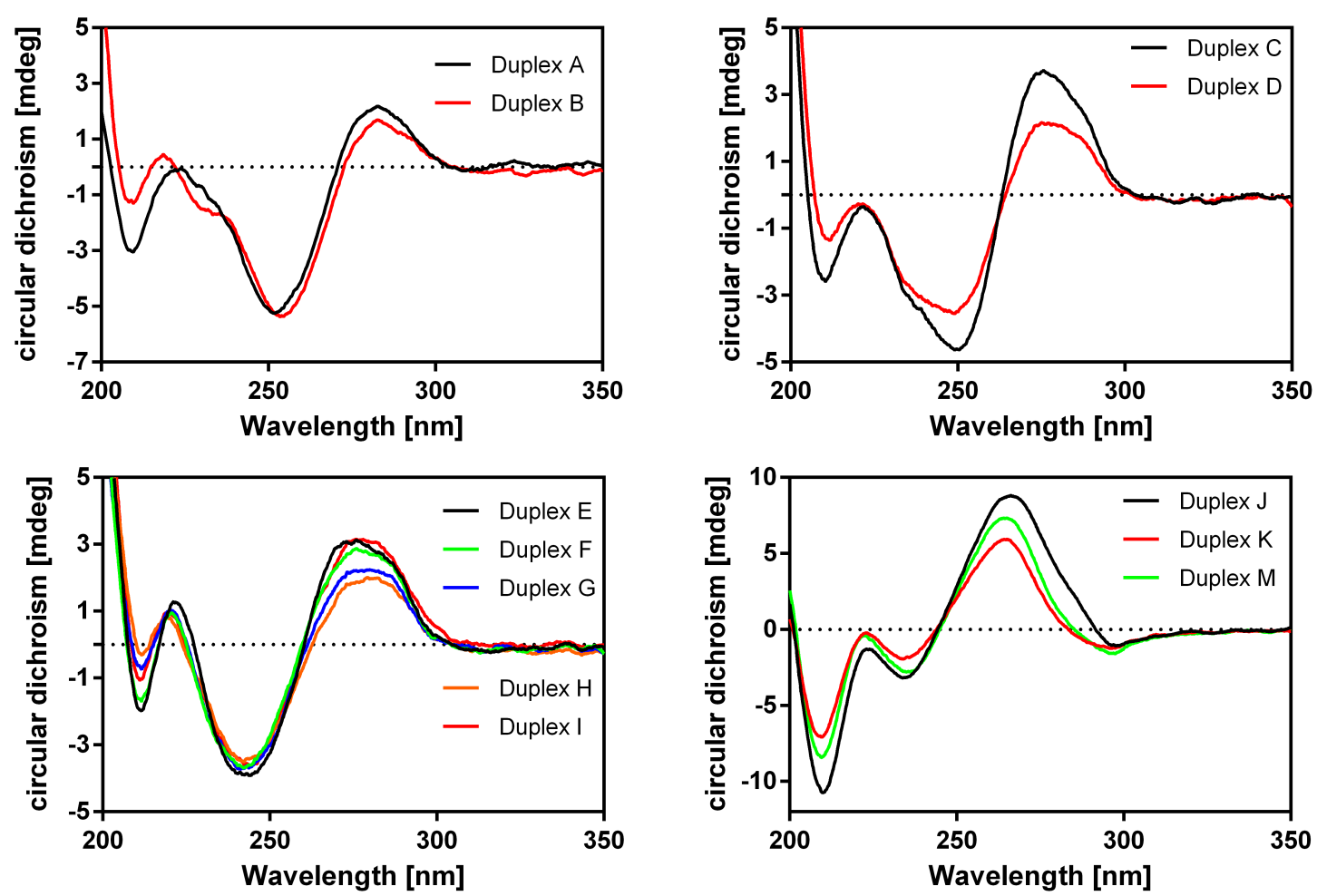

Figure S32. CD spectra of unmodified DNA and RNA duplexes along with their EC and EÇm labeled counterparts. 


\section{Thermal denaturing experiments of spin-labeled oligonucleotides}

UV melting curve of duplexes
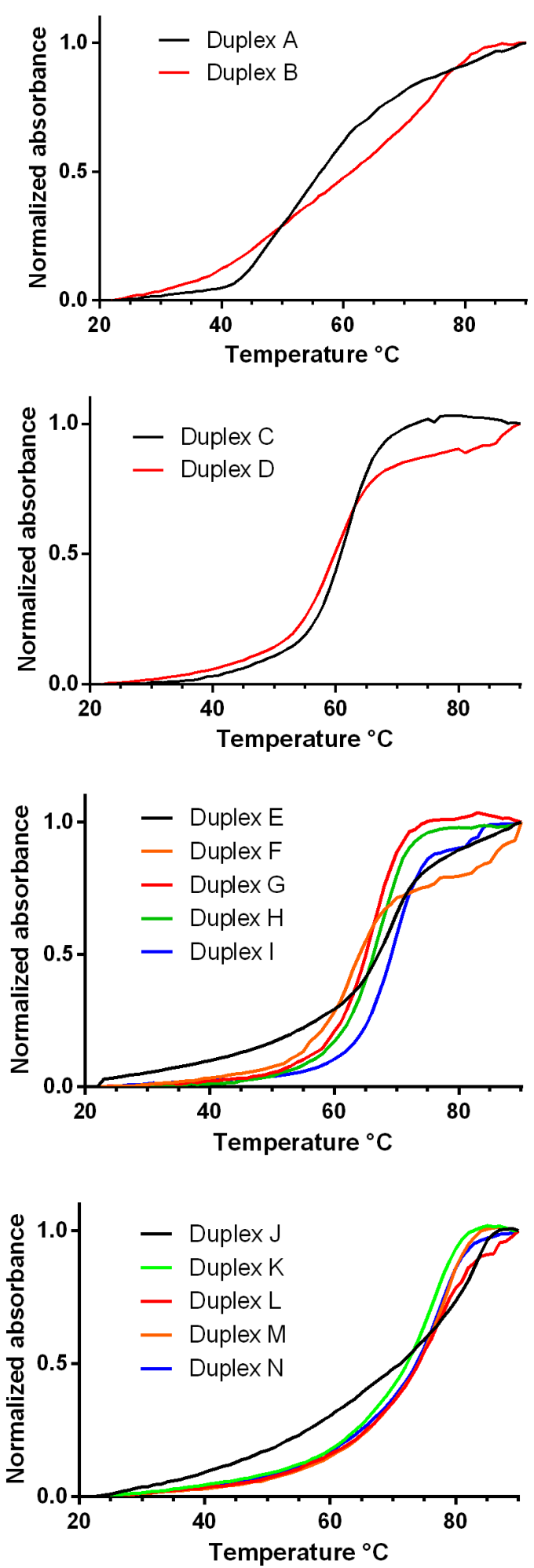

Derivative of the absorbance


Figure S33. Thermal denaturing analysis of duplexes. 
CW-EPR spectra of spin labeled oligonucleotides

EÇ labeled DNA (single strands)
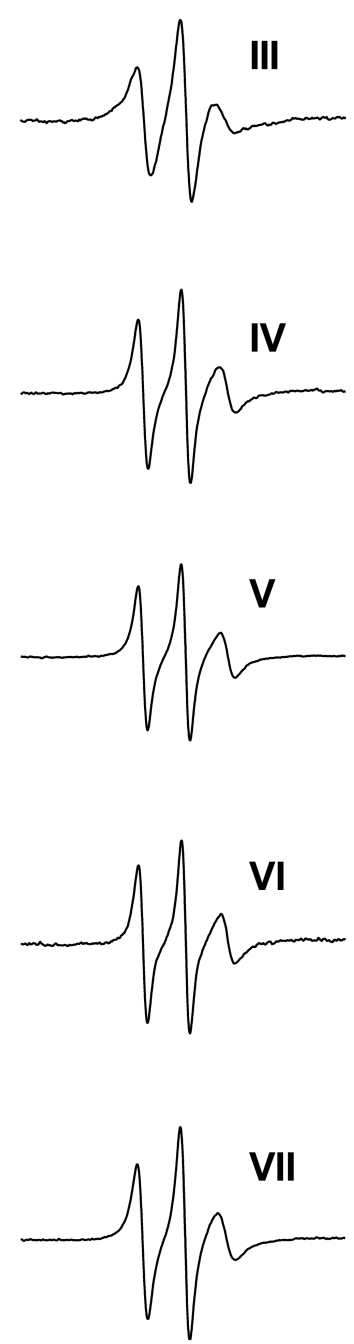

EÇ labeled DNA (duplexes)
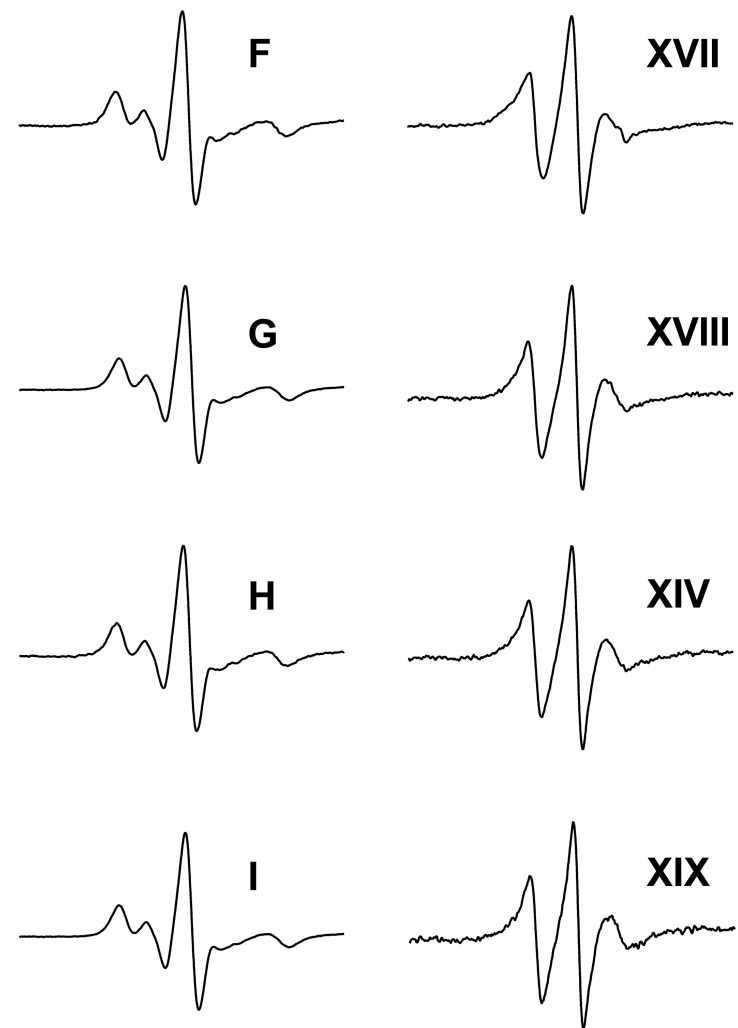

EÇm labeled RNA (single strands)
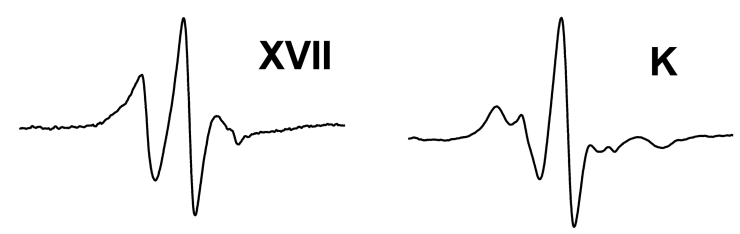

EÇm labeled RNA (duplexes)


Figure S34. EPR spectra of spin-labeled oligonucleotides. 


\section{References}

[1] H. Y. Juliusson, A.-L. J. Segler, S. T. Sigurdsson, Eur. J. Org. Chem. 2019, 2019, 3799-3805.

[2] P. Cekan, A. L. Smith, N. Barhate, B. H. Robinson, S. T. Sigurdsson, Nucleic Acids Res. 2008, $36,5946-5954$. 